\title{
CPEB2-activated PDGFRa mRNA translation contributes to myofibroblast proliferation and pulmonary alveologenesis
}

Yen-Ting Lai ${ }^{1 \dagger}$, Hsu-Wen Chao ${ }^{2,3+}$, Alan Chuan-Ying Lai ${ }^{1}$, Shu-Hui Lin ${ }^{2,3}$, Ya-Jen Chang ${ }^{1 *}$ and Yi-Shuian Huang ${ }^{1 *}$

\begin{abstract}
Background: Alveologenesis is the final stage of lung development to form air-exchanging units between alveoli and blood vessels. Genetic susceptibility or hyperoxic stress to perturb this complicated process can cause abnormal enlargement of alveoli and lead to bronchopulmonary dysplasia (BPD)-associated emphysema. Plateletderived growth factor receptor a (PDGFRa) signaling is crucial for alveolar myofibroblast (MYF) proliferation and its deficiency is associated with risk of BPD, but posttranscriptional mechanisms regulating PDGFRa synthesis during lung development remain largely unexplored. Cytoplasmic polyadenylation element-binding protein 2 (CPEB2) is a sequence-specific RNA-binding protein and translational regulator. Because CPEB2-knockout (KO) mice showed emphysematous phenotypes, we investigated how CPEB2-controlled translation affects pulmonary development and function.
\end{abstract}

Methods: Respiratory and pulmonary functions were measured by whole-body and invasive plethysmography. Histological staining and immunohistochemistry were used to analyze morphology, proliferation, apoptosis and cell densities from postnatal to adult lungs. Western blotting, RNA-immunoprecipitation, reporter assay, primary MYF culture and ectopic expression rescue were performed to demonstrate the role of CPEB2 in PDGFRa mRNA translation and MYF proliferation.

Results: Adult CPEB2-KO mice showed emphysema-like dysfunction. The alveolar structure in CPEB2-deficient lungs appeared normal at birth but became simplified through the alveolar stage of lung development. In CPEB2-null mice, we found reduced proliferation of MYF progenitors during alveolarization, abnormal deposition of elastin and failure of alveolar septum formation, thereby leading to enlarged pulmonary alveoli. We identified that CPEB2 promoted PDGFRa mRNA translation in MYF progenitors and this positive regulation could be disrupted by $\mathrm{H}_{2} \mathrm{O}_{2}$ a hyperoxia-mimetic treatment. Moreover, decreased proliferating ability in KO MYFs due to insufficient PDGFRa expression was rescued by ectopic expression of CPEB2, suggesting an important role of CPEB2 in upregulating PDGFRa signaling for pulmonary alveologenesis.

Conclusions: CPEB2-controlled translation, in part through promoting PDGFRa expression, is indispensable for lung development and function. Since defective pulmonary PDGFR signaling is a key feature of human BPD, CPEB2 may be a risk factor for BPD.

Keywords: Alveologenesis, Bronchopulmonary dysplasia, CPEB2, Myofibroblast, PDGFRa, Translational control

\footnotetext{
* Correspondence: yajchang@ibms.sinica.edu.tw; yishuian@ibms.sinica.edu.tw

${ }^{\dagger}$ Yen-Ting Lai and Hsu-Wen Chao contributed equally to this work.

${ }^{1}$ Institute of Biomedical Sciences, Academia Sinica, 128 Sec. 2, Academia Rd,

Taipei 11529, Taiwan

Full list of author information is available at the end of the article
}

\section{$\triangle B M C$}

(c) The Author(s). 2020 Open Access This article is licensed under a Creative Commons Attribution 4.0 International License, which permits use, sharing, adaptation, distribution and reproduction in any medium or format, as long as you give appropriate credit to the original author(s) and the source, provide a link to the Creative Commons licence, and indicate if changes were made. The images or other third party material in this article are included in the article's Creative Commons licence, unless indicated otherwise in a credit line to the material. If material is not included in the article's Creative Commons licence and your intended use is not permitted by statutory regulation or exceeds the permitted use, you will need to obtain permission directly from the copyright holder. To view a copy of this licence, visit http://creativecommons.org/licenses/by/4.0/. The Creative Commons Public Domain Dedication waiver (http://creativecommons.org/publicdomain/zero/1.0/) applies to the data made available in this article, unless otherwise stated in a credit line to the data. 


\section{Background}

The development of the rodent lung starts from the specification and proliferation of tracheal and lung cell progenitors from the foregut endoderm at embryonic day 9.5. Subsequently, coordinated branching morphogenesis and vascular development result in a tree-like structure of epithelial tubules with differentiated airways and saccules. After birth, alveologenesis further remodels primitive saccules into mature alveoli with coordinated expansion of the microcapillary network for efficient gas exchange across the epithelial and endothelial barriers $[1,2]$. Postnatal alveolar development is characterized by the expansion of epithelial cells lining primitive saccules and the formation of secondary septa by alveolar myofibroblasts (MYFs). MYFs differentiated from their progenitors migrate to the tips of growing septa and secret extracellular matrix proteins, such as collagen and tropoelastin, which provide the driving force for septal protrusion [3].

Previous studies identified that $\alpha$-smooth muscle actinpositive $\left(\alpha \mathrm{SMA}^{+}\right)$MYFs are derived from alveolar MYF precursor cells expressing platelet-derived growth factor receptor $\alpha$ (PDGFR $\alpha)[4,5]$. Activation of PDGFR $\alpha$ in response to epithelial cell-secreted PDGF-A is crucial for the proliferation, differentiation and migration of MYFs [6]. The PDGF signaling family of proteins includes 4 ligands (PDGF-A, B, C and D) and 2 receptors (PDGFR $\alpha$ and $\beta)[6,7]$. Both PDGFR $\alpha$ and $\beta$ are receptor tyrosine kinases with an extracellular ligand-binding motif, a transmembrane region and an intracellular tyrosine kinase domain $[8,9]$. PDGF-A and -B form as a disulfide-linked homo- or hetero-dimer: PDGF-AA, PDGF-BB or PDGF$A B$. PDGFR $\beta$ interacts with only $B$ chain-containing PDGF isoforms, but PDGFR $\alpha$ can bind all 3 isoforms with different affinities in vitro. Ligand binding-mediated dimerization of PDGFRs triggers autophosphorylation of the tyrosine residues in their intracellular kinase domains $[10,11]$ and downstream signaling cascades, including the phosphoinositide 3-kinase/Akt/mammalian target of rapamycin pathway [12] and mitogen-activated protein kinase pathway [13-15].

PDGFR $\alpha$ signaling regulates proliferation, differentiation, migration and/or apoptosis in many cell types, so it is important for gastrulation and the development of various tissues including lung [16]. PDGFR $\alpha$-knockout (KO) mice die during embryonic development, with incomplete cephalic closure and abnormal somite patterning [17]. PDGF-A and PDGFR $\alpha$ are essential for alveolar MYF development and pulmonary alveologenesis. PDGF-A-null mice show high lethality and lack alveolar MYF progenitors and MYFs, so surviving mice show failure to form alveolar septa and consequently emphysema-like phenotypes [18, 19]. A recent study showed that PDGF-A in type II alveolar epithelial cells (AECIIs), whose synthesis is regulated by Notch 2 signaling, secretes as a paracrine signal to activate PDGFR $\alpha$ of alveolar MYF progenitors. Epithelium-specific inactivation of Notch 2 results in decreased PDGF-A expression and impaired alveologenesis [20]. Similarly, neonatal rats injected with a PDGFR antagonist from postnatal day 1 (P1) to P7 showed reduced alveolar cell proliferation and defective septation to cause alveolar space enlargement with abnormal elastin deposition continuously to adulthood [21]. Thus, a transient downregulation in PDGFR $\alpha$ signaling during early infancy produces long-lasting changes in lung architecture and alveolar stretch ability to cause emphysematous dysfunction, reminiscent of bronchopulmonary dysplasia (BPD).

BPD is a chronic lung disease of hypoalveolarization occurring in premature infants, especially those under mechanical ventilation. PDGFR $\alpha$ level in lung mesenchymal stromal cells (MSCs) isolated from premature infants under ventilation was reduced in those in whom BPD later developed [22]. Similarly, neonatal mice exposed to hyperoxia showed BPD-like phenotypes with reduced development of PDGFR $\alpha$-positive alveolar tips [22]. Despite the implication of defective PDGFR $\alpha$ signaling in BPD, much less is known about the molecular mechanism regulating PDGFR $\alpha$ expression during alveologenesis.

Cytoplasmic polyadenylation element-binding protein 2 (CPEB2) is a sequence-specific RNA-binding protein widely present in various tissues with high expression in the brain, liver and testes [23]. CPEB2 can bind to eukaryotic translation elongation factor 2 (eEF2) and downregulate eEF2's GTPase activity to impede translation of hypoxia-inducible factor $1 \alpha$ mRNA $[24,25]$. Similar to other CPEB family proteins, CPEB2 can also promote translation of some of its target mRNAs [26, 27]. Previously, we found that CPEB2-KO neonatal mice showed aberrant respiration with frequent apnea and died mostly within 3 days after birth. Although enhanced cholinergic transmission-induced bronchoconstriction accounts for some apneic episodes and possible mortality in CPEB2-KO neonates [23], inhalation of an anticholinergic bronchodilator only partially rescued the respiratory apnea in CPEB2-KO pups without improving survival. Thus, hyperactivated cholinergic signaling contributes to only some but not all respiratory abnormalities in CPEB2-KO mice.

In the present study, we identified that CPEB2 regulates pulmonary alveologenesis by promoting PDGFR $\alpha$ mRNA translation in alveolar MYF progenitors. CPEB2 deficiency renders insufficient PDGFR $\alpha$ signaling to impair proliferation of MYF progenitors and decrease the population and localization of MYFs at the growing tips of septa, thereby leading to enlarged pulmonary alveoli with irregular elastin deposition. Consequently, CPEB2$\mathrm{KO}$ mice surviving to adulthood show pulmonary 
dysfunction with decreased elastance and resistance, similar to other emphysema-like mouse models and human BPD [28-30]. Moreover, we analyzed 2 GEO datasets and found decreased CPEB2 mRNA level in umbilical cords of BPD infants [31] and hyperoxiaexposed pulmonary MSCs [32]. In summary, CPEB2 plays an important role in alveologenesis and may be a potential therapeutic target for BPD.

\section{Methods}

\section{Animals and anesthetization}

All protocols for animal experiments were approved by Institutional Animal Care and Utilization Committee of Academia Sinica. CPEB2-WT and -KO mice were littermates from heterozygous matings, and their genotypes were determined by PCR as described previously [23]. Mice were maintained in a 12-h light, $\sim 200 \mathrm{~lx}$ fluorescent light on at $8 \mathrm{am}$, and 12-h dark cycle with food and water ad libitum. To avoid the circadian effect on gene expression, mice were anesthetized and sacrificed at $\sim 4$ $\mathrm{pm}$ to collect lung tissues for all experiments. P0 and P3 pups were anesthetized by hypothermia, and mice of older ages were anesthetized with avertin $(250 \mathrm{mg} / \mathrm{kg})$ unless otherwise specified.

\section{Whole-body plethysmography}

The Buxco plethysmographic system was used to record mouse respiration. Adult mice at 2-3 months old were habituated for $30 \mathrm{~min}$ in the animal chambers connected to the bias flow regulator, followed by $1-\mathrm{h}$ recording. Breathing-induced pressure changes between the animal and reference chambers were detected by the transducer, and the barometric signals transferred to the Buxco MaxII amplifier were filtered through a bandwidth of 0 $15 \mathrm{~Hz}$ to subtract background noises. Respiratory parameters from 1-h recording were analyzed by using FinePointe (Buxco system, DSI). To induce airway hyperreactivity, nebulized methacholine at increasing concentrations was given and the value of Penh was calculated to determine airway resistance $[33,34]$.

\section{Analysis of airway hyper-reactivity in adult mice}

Eight-week old mice were anesthetized with pentobarbital (Sigma-Aldrich, St Louis, MO) at $100 \mathrm{mg} / \mathrm{kg}$ of body weight. Anesthetized mice were tracheotomized, intubated, and mechanically ventilated at a tidal volume of $0.2 \mathrm{ml}$ and a frequency of 150 breathes $/ \mathrm{min}$. Airway resistance and dynamic compliance in sedated mice challenging with increasing doses $(1.25$ to $40 \mathrm{mg} / \mathrm{ml})$ of methacholine were measured by invasive plethysmography via the FinePointe RC system (Buxco Research Systems), according to the established protocol [35]. Changes in lung volume and tracheal pressure detected by two pressure sensors for $3 \mathrm{~min}$ after every dose of methacholine were calculated to derive average lung resistance, elastance and dynamic compliance.

\section{Analysis and counting of bronchoalveolar lavage fluid (BALF) cells}

BALF was collected from tracheotomized mice by instilling $1 \mathrm{ml}$ of phosphate buffered saline (PBS) containing $2 \%$ fetal calf serum (FCS) through a tracheal cannula, followed by aspiration and a second lavage of the same volume. The pooled BALF was centrifuged at $400 \mathrm{xg}$ for $5 \mathrm{~min}$. The pelleted BALF cells were resuspended in $\mathrm{PBS} / 2 \%$ FCS, attached to cytospin slides by centrifugation, stained with Diff-Quik solution (Sysmex, Taiwan) and then counted.

\section{Plasmid construction}

Mouse PDGFR $\alpha$ 3'-UTR was PCR-amplified from lung cDNA by using the primers 5 '-CTAGTCTAGACTGA CACGCTCCGGGTATC-3' and 5' -ACGCGTCGAC AAGTCATATATAATAAATCATTTATTGAAATA

TAAAG-3'. The amplified DNA fragment was cloned to the pGL3 promoter plasmid (Promega) by using XbaI and SalI cloning sites. The resulting plasmid was digested with $\mathrm{XbaI}$ and self-ligated to generate the 3' UTR 1-kb construct. The 3'UTR $\triangle$ CPE construct was obtained by inverse PCR amplification by using the PDGFR $\alpha$ 3'-UTR plasmid and the primer pair 5' AGCCTCTGTTTGTTGCTTCTGATGACAATCAAAG CTTGCC-3' and 5'-GGCAAGCTTTGATTGTCA TCAGAAGCAACAAACAGAGGCT-3'. Construction of the lentiviral vector expressing myc-CPEB2 was described [26].

\section{Luciferase reporter assay}

HeLa cells (ATCC, CCL-2, have been examined without mycoplasma) were cultured in DMEM supplemented with $10 \%$ fetal bovine serum (FBS). Cells were subcultured in a 12-well plate 1 day before transfection. Each well of cells was transfected with the DNA mixture containing $0.5 \mu \mathrm{g}$ plasmid expressing firefly luciferase reporter appended with or without PDGFR $\alpha$ 3'-UTR, $0.07 \mu \mathrm{g}$ Renilla luciferase construct, and $0.5 \mu \mathrm{g}$ of the plasmid expressing myc tag or myc-CPEB2 by using $\mathrm{Li}$ pofectamine 2000 (Invitrogen). The transfected cells were harvested the next day for dual luciferase assay (Promega) and immunoblotting.

\section{RNA-immunoprecipitation (RNA-IP)}

A P10 mouse lung was homogenized in $2 \mathrm{ml}$ lysis buffer [50 mM HEPES, pH 7.4, $150 \mathrm{mM} \mathrm{NaCl}, 1 \mathrm{mM}$ EDTA, $0.5 \%$ Triton X-100, $0.5 \mathrm{mM}$ DTT, $1 \mathrm{X}$ protease inhibitor mixture (Roche), and $40 \mathrm{U} / \mathrm{ml}$ RNase inhibitor (TOOLS Biotech)], incubated on ice for $30 \mathrm{~min}$ and then centrifuged at $12,000 x g$ for $15 \mathrm{~min}$. The supernatants were 
equally divided and incubated with $10 \mu$ protein $G$ beads bound with $10 \mu \mathrm{g}$ CPEB2 or control IgG for $3 \mathrm{~h}$ at $4{ }^{\circ} \mathrm{C}$. The beads were washed 3 times with $700 \mu$ lysis buffer to remove non-specific binding. Approximately $20 \%$ beads were used for immunoblotting and the rest were incubated in elution buffer (100 mM Tris-Cl, pH 8.0, $10 \mathrm{mM}$ EDTA, $1 \%$ SDS, $20 \mu \mathrm{g} / \mathrm{ml}$ proteinase $\mathrm{K}$ ) at $55^{\circ} \mathrm{C}$ for $30 \mathrm{~min}$, followed by phenol/chloroform extraction and isopropanol precipitation. The isolated RNAs were reverse transcribed by using an oligo-dT/random primer mixture and ImPromII Reverse Transcriptase (Promega). Quantitative PCR involved the Universal Probe Library and Lightcycler 480 system (Roche). The comparative $\mathrm{Ct}$ (threshold cycle value) method with the nontargeted RNA, glyceraldehyde-3-phosphate dehydrogenase (GAPDH) or $\beta$-actin mRNA as a reference, was used to calculate relative expression. The PCR primers used were PDGFR $\alpha$, 5'-GCGAGTTTAATGTTTATGCCTTG-3' and 5'-GGCACAGGTCACCACGAT-3'; PDGF-A, 5'-GATGAGGACCTGGGCTTG-3' and 5'-GATCAACTCC CGGGGTATCT-3': GAPDH, 5'-AAGAGGGATGCTCC CTTAC-3' and 5'-CCATTTTGTCTACGGGACGA-3'; $\beta$ actin, 5'-CTAAGGCCAACCGTGAAAAG-3' and 5'ACCAGAGGCATACAGGGACA-3'.

\section{Primary culture of pulmonary MYFs}

To culture primary MYFs, anesthetized P8-10 CPEB2 wild type (CPEB2-WT) and CPEB2-KO mice were perfused cardially with cold PBS and bronchoalveolar lavage. Isolated pulmonary tissues were washed 3 times with cold PBS and then digested in DMEM containing 1 $\mathrm{mg} / \mathrm{ml}$ collagenase I, $2.5 \mathrm{mg} / \mathrm{ml}$ trypsin and $2 \mathrm{mg} / \mathrm{ml}$ DNase I at $37^{\circ} \mathrm{C}$ for $30 \mathrm{~min}$ in $5 \% \mathrm{CO}_{2}$ incubator. Liberated cells were filtered through sterile mesh, and pelleted at $200 x g$ for $5 \mathrm{~min}$. Cell pellets were resuspended and cultured at $\sim 10^{5} / \mathrm{cm}^{2}$ in DMEM containing 10\% FBS and antibiotics. MYF cultures, in which $\sim 75-80 \%$ of cells expressed aSMA, used in this study were kept under 5 passages. For western blot and RT-qPCR experiments in Fig. 6d-f and Additional file 1: Figure S6, primary MYFs were cultured and processed at the indicated time without subculture.

\section{In vitro wound healing assay}

MYFs were plated at $10^{5} /$ well in 12 -well plates and grown for 2-3 days until $>95 \%$ confluency. Confluent cells were then starved in DMEM containing 0.5\% FBS for $24 \mathrm{~h}$, wounded with a pipette tip, rinsed once with 0.5\% FBS DMEM, then incubated in 0.5\% FBS DMEM for $24 \mathrm{~h}$. Live imaging under a Leica DMI 6000B microscope was acquired for $24 \mathrm{~h}$. Cell repopulation in the wounded area was analyzed at $0,6,12,18$ and $24 \mathrm{~h}$ after wounding. Cell polarity was determined by staining a Golgi-resident protein, GM130, at $6 \mathrm{~h}$ after scratching. Polarized cells were defined by their GM130 signal located within a $60^{\circ}$ angle perpendicular to the migration direction toward the scratched area.

\section{PDGF-A-induced growth assay}

Cultured MYFs were infected with lentiviruses expressing GFP or myc-CPEB2 at DIV3, subcultured to coverslip-containing 12 -well plate at $10^{5} /$ well at DIV4 and then serum-starved at DIV5 for $24 \mathrm{~h}$ to arrest cells at G0/G1 phase, followed by the treatment of $50 \mathrm{ng} / \mathrm{ml}$ PDGF-A (PROSPEC, cat\# cyt-590) for $3 \mathrm{~h}$ and $6 \mathrm{~h}$. PDGF-A-treated MYFs were immunostained with Ki67 and $\alpha$ SMA antibodies to identify proliferating MYFs, which exit G0 phase and re-enter cell cycle to express Ki67 [36]. The percent of $\alpha \mathrm{SMA}^{+}$MYFs with Ki67 ${ }^{+}$signal was determined by using Cell Counter function in ImageJ software (National Institute of Health).

\section{Antibodies and chemicals}

Antibodies used in the study are: $\alpha$ SMA (ab7817) and Ki67 (ab15580) from Abcam; GM130 (610822) from BD Biosciences; cleaved caspase-3 (9664S) and PDGFR $\alpha$ (3174S) from Cell Signaling Technology; BrdU (GTX26326) from GeneTex; pro-surfactant protein C (10774-1-AP) from Proteintech; caveolin-1 (sc-894), Hopx (sc-398,703) and GAPDH (sc25778) from Santa Cruz Biotechnology; $\beta$-actin (A5441) and $\alpha$-tubulin (T5168) from Sigma-Aldrich; and AlexaFluor 488, 594 or 647-conjugated secondary antibodies from Invitrogen. Chemicals used in the study are: ProLong antifade (P36930) and 4',6-diamidino-2-phenylindole (DAPI, D1306) reagents from Invitrogen; and Avertin (T48402), methacholine (A2251) and 5-bromo-2'-deoxyuridine (B9285) from Sigma-Aldrich.

\section{Immunoblotting}

Protein extracts were prepared from equal amounts of lung or cultured cells in Laemmli sample buffer supplemented with 1X protease inhibitor cocktail (Roche) and phosphatase inhibitors (Tocris). Homogenates were boiled at $55^{\circ} \mathrm{C}$ for $15 \mathrm{~min}$ and then centrifuged at 14,000 $x g$ for $10 \mathrm{~min}$ to remove any insoluble debris. Protein lysates were resolved by $10 \%$ SDS-PAGE mini-gels, transferred to nitrocellulose membranes. The membranes were then blocked in 5\% skim milk in 1X TBST (TBS with $0.05 \%$ Tween 20) for $60 \mathrm{~min}$, followed by the incubation of primary antibodies at $4{ }^{\circ} \mathrm{C}$ overnight. Horse peroxidase-conjugated secondary antibodies were used for enhanced chemiluminescence detection (ECL-Prime, GE Healthcare Life Sciences) by Image Quant LAS 4000 (Fujifilm).

\section{Immunohistochemistry and image acquisition}

To detect proliferating cells with thymidine analogue BrdU, mice at different ages were injected with BrdU at 
$12 \mathrm{pm}(10 \mathrm{mg} / \mathrm{kg})$ and sacrificed $4 \mathrm{~h}$ later to collect lung tissue. After anesthetization, the trachea was cannulated and the lung was inflated by installation of $4 \%$ formaldehyde in PBS at pressure $25 \mathrm{~cm} \mathrm{H}_{2} \mathrm{O}$ for 2-month-old mice, $20 \mathrm{cmH}_{2} \mathrm{O}$ for P14 and P21 mice, and $12 \mathrm{cmH}_{2} \mathrm{O}$ for P10 and P7 mice for $10 \mathrm{~min}$. Inflated lungs were ligated and fixed for $24 \mathrm{~h}$ at $4{ }^{\circ} \mathrm{C}$ before embedding in paraffin. The lung sections after dewaxing and rehydration procedures were boiled in $10 \mathrm{mM}$ sodium citrate buffer $\mathrm{pH} 6$ for $5 \mathrm{~min}$ to retrieve antigens, followed by immunofluorescence staining. All staining procedures were performed at room temperature with solutions prepared in PBS. The lung sections (5- $\mu \mathrm{m}$ thick) were permeabilized and blocked in PBS containing 10\% horse serum, 3\% bovine serum albumin, and $0.3 \%$ Triton X100 for $1 \mathrm{~h}$, then incubated with the designated primary antibodies overnight at $4{ }^{\circ} \mathrm{C}$. After three washes with PBS, tissues were incubated with the corresponding Alexa Fluor-conjugated secondary antibodies for $1 \mathrm{~h}$. Histological staining with hematoxylin and eosin was performed by the institutional Pathology Core staff. Sections after the removal of paraffin were stained with hematoxylin and eosin. For elastic fiber staining, lung sections after dewaxing and rehydration were rinsed with $70 \%$ ethanol and stained with aldehyde-fuchsin solution (1 g pararosanilin, $1 \mathrm{ml}$ concentrated hydrochloric acid and $2 \mathrm{ml}$ paraldehyde in $100 \mathrm{ml} 70 \%$ ethanol) for $5 \mathrm{~min}$. The slides were rinsed with $70 \%$ ethanol and washed with $\mathrm{H}_{2} \mathrm{O}$ for 3 times. Fluorescent images were acquired under a LSM780 confocal microscopy (Carl Zeiss) or Axio Imager Z1 fluorescence microscopy (Carl Zeiss).

\section{D image acquisition and reconstruction}

P10 mice were injected with BrdU, anesthetized and perfused with $4 \%$ formaldehyde in PBS as described in the previous paragraph, except overnight post-fixed lungs were immersed in 20 and $30 \%$ (wt/vol) sucrose/PBS overnight and then were embedded in Tissue-Tek OCT compound. Lungs were sectioned at $60 \mu \mathrm{m}$ by using a Leica CM1850 cryostat. Lung sections were immersed with the antigen retrieval buffer (Tris/EDTA, $\mathrm{pH}$ 9.0) at $95^{\circ} \mathrm{C}$ for $20 \mathrm{~min}$, permeabilized with $0.5 \%$ Triton X-100/ PBS for $2 \mathrm{~h}$ and blocked in 10\% horse serum and 3\% BSA for $2 \mathrm{~h}$ at room temperature, followed by the incubation of primary antibodies in $0.5 \%$ Triton X-100/PBS at $4{ }^{\circ} \mathrm{C}$ overnight. After three washes of PBS, tissues were incubated with the corresponding Alexa Fluorconjugated secondary antibodies at $4{ }^{\circ} \mathrm{C}$ overnight, washed with PBS for 3 times and then mounted in Antifade Mounting Medium (VECTASHIELD). Serial optical Z-sections of fluorescent images were acquired under a LSM780 confocal microscopy with a Plan-Apochromat $20 \mathrm{x} / 0.8 \mathrm{M} 27$ objective at the resolution of $2048 \times 2048$ and the total depth of $60 \mu \mathrm{m}$ with $0.8 \mu \mathrm{m}$ per Z-step.
Three dimensional images were reconstructed by using ZEN black image analysis software (Carl Zeiss, 2011 SP7 FP3, version 14.0.0.0).

\section{Image quantification}

Immunohistochemical and histological images acquired from 2 to 3 pulmonary sections per mouse, at least 5 mice per genotype at every postnatal age, were used for analysis. A random selection of 5 imaging fields (each field $\sim 45,000 \mu \mathrm{m}^{2}$ ) from 2 to 3 pulmonary sections were analyzed independently by 3 undergraduate students using cell counter and multi-measure functions in ImageJ $1.47 \mathrm{v}$. Two close values from the 3 independent analyses were averaged to derive quantified results in Figs. 2b, c, 3a-d, 4c-e and 5a'-b". For scoring the density, length, and number of elastic fibers, only signals within alveolar sacs were considered and those located in vessels, alveolar ducts, bronchioles and bronchia were omitted (an example in Additional file 1: Figure S1). For counting PDGFR $\alpha^{+}$and $\alpha \mathrm{SMA}^{+}$double-positive cells, cells with both immunofluorescence signals surrounding more than a half of nucleus were counted, similarly for single positive cells (examples in Additional file 1: Figure S2). To normalize unequivalent alveolar airspace in WT and CPEB2-KO lungs, the cell density was calculated by dividing cell numbers with DAPI-positive (nuclei) area. The alveolar size was determined by morphometric lung measurements of mean linear intercept (MLI) [37]. MLI was determined by drawing 5 lines of $0.5-\mathrm{mm}$ length over alveoli in each image, counting the intercepts with alveolar walls for all 5 lines and dividing $2.5 \mathrm{~mm}$ by the number of intercepts.

\section{Analysis of gene expression omnibus (GEO) datasets}

To explore the expression profiles of CPEB2 and PDGFR $\alpha$ mRNA in BPD-related research, we used GSE8586 and GSE99633 datasets from the GEO database (http://www.ncbi.nlm.nih.gov/geo/). GSE8586 study involved using Affymetrix Human Genome U133 Plus 2.0 array to profile transcriptomes of umbilical cord tissues isolated from premature newborns in whom BPD developed or not [31]. The other GSE99633 study involved isolated $\mathrm{CD} 146^{+}$lung MSCs from P12 rat pups exposed to $95 \%$ or $21 \% \mathrm{O}_{2}$ from birth to $\mathrm{P} 10$ [32]. The mRNA levels of designated targets were extracted.

\section{Data and statistical analyses}

Mice and cultured cells were randomly assigned for time-course study and drug treatment, respectively. Imaging fields were randomly selected during image acquisition. The sample size among experimental groups was kept as equal as possible. GraphPad Prism 5.0 and Excel software were used to produce graphs and for statistical analysis. One-way and two-way ANOVA and two-tailed 
Student's $t$ test were used as appropriate for statistical analysis. Bonferroni's multiple comparison test was used for comparisons among multiple conditions after ANOVA analysis. Sample numbers and statistical results are indicated in the figure legends. $P<0.05$ was considered statistically significant.

\section{Results}

\section{Adult CPEB2-KO mice show emphysema and alveolar} enlargement

CPEB2-KO mice are born alive, but about two-thirds die before weaning. We previously found that loss of CPEB2 in the dorsal motor nucleus of the vagus neurons leads to translational upregulation of choline acetyltransferase, thereby increasing pulmonary acetylcholine level to induce bronchoconstriction-associated apnea in neonatal pups [23]. However, surviving CPEB2-KO mice can live for at least 1 year without obvious physical problems except for reduced thermogenesis in brown adipose tissues [27]. To investigate whether the abnormal breathing patterns in neonatal CPEB2-KO mice persist into adulthood, we used a non-invasive whole-body plethysmography (WBP) to analyze their breathing patterns. Respiratory parameters, including breathing frequency, tidal volume, peak inspiratory flow (PIF), peak expiratory flow (PEF), inspiratory time and expiratory time were comparable between CPEB2 wild-type (CP2WT) and CPEB2-KO (CP2KO) adult mice (Fig. 1a). Bronchoconstriction-associated apnea phenotypes, such as aberrant breathing pattern, reduced PIF and PEF, in CPEB2-KO neonates [23] were not observed in adults.

Unexpectedly, adult CPEB2-KO mice exhibited reduced airway resistance in response to methacholine challenges, with lower value of enhanced pause (Penh) measured by WBP in comparison with WT mice (Fig. 1b, $P<0.001)$. In addition to the non-invasive measurement, we further used an invasive forced oscillatory system to directly measure airway impedance in anesthetized CPEB2-WT and -KO adult mice. Methacholine-induced airway resistance was significantly reduced in CPEB2KO mice (Fig. 1c, $P<0.001$ ), in contrast to mice with cholinergic neuron-specific ablation of Cpeb2 showing airway hyper-reactivity [23]. Thus, defects other than elevated cholinergic transmission should exist in global

a Plethymography
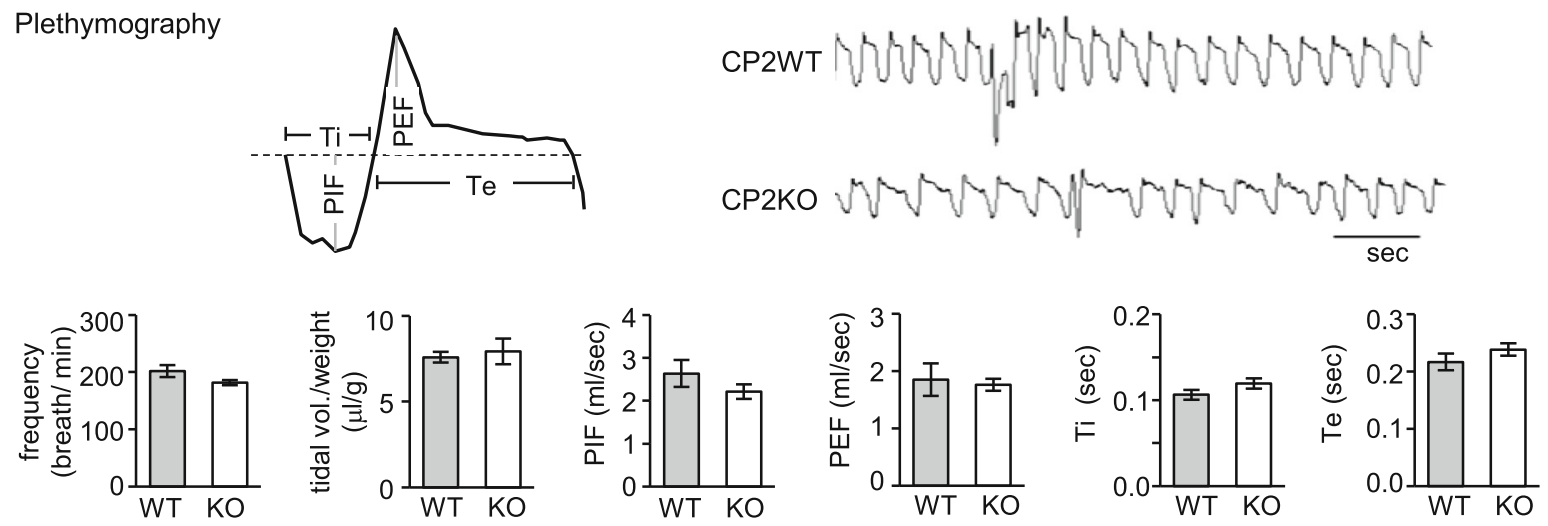

\section{b Plethymography}

\section{Forced oscillatory system}
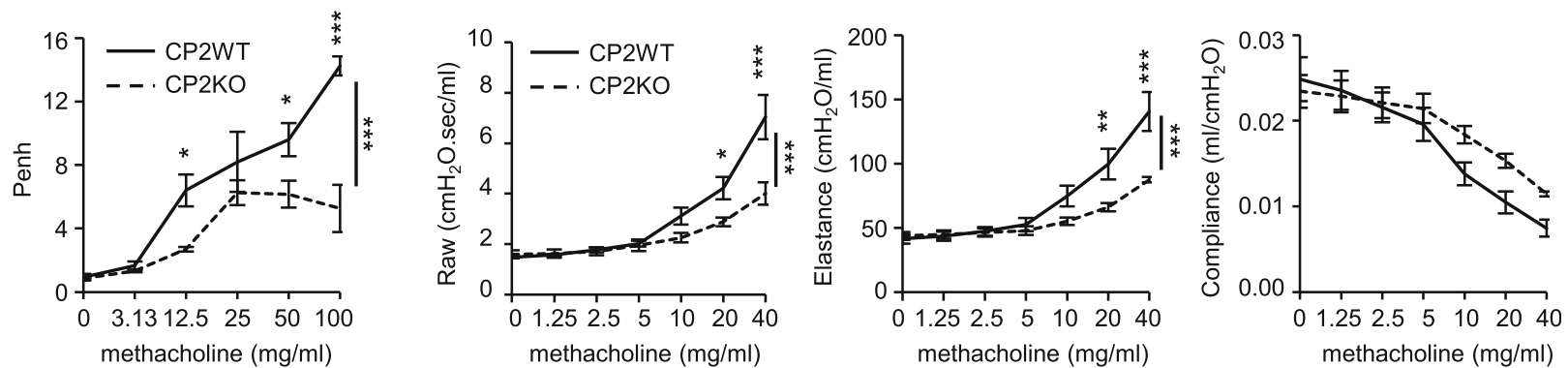

Fig. 1 Abnormal lung function in CPEB2-KO mice. a Whole-body plethysmographic recording of CPEB2-WT (CP2WT) and CPEB2-KO (CP2KO) mice at age $2-3$ months ( $n=7$ per group). Representative recorded traces and results of respiratory frequency, normalized tidal volume (Vt/ body weight), peak inspiratory and expiratory flow (PIF and PEF), inspiratory and expiratory time (Ti and Te). $\mathbf{b}$ Values of enhanced pause (Penh) indicating airway reactivity determined by whole body plethysmography in adult CP2WT and CP2KO mice ( $n=4$ per group) with increasing doses of inhaled methacholine (Mch). c Airway resistance, pulmonary elastance and dynamic compliance in adult tracheotomized mice (WT/KO= 4/5) challenged with increasing doses of Mch determined by an invasive forced oscillatory system. Data are mean \pm s.e.m., ${ }^{*} P<0.05,{ }^{* *} P<0.01$ and ${ }^{* * *} P<0.001$, by two-way ANOVA and Bonferroni post-hoc test 
CPEB2-KO mice to cause opposite outcomes in methacholine-triggered airway response. In addition, the decrease of pulmonary elastance (Fig. 1c, $P<0.001$ ) and the increased trend of dynamic compliance (Fig. 1c, $P=$ 0.29) in CPEB2-KO mice indicated their compromised lung function similar to other emphysematous mice [28-30, 38, 39].

We then performed morphometric lung measurements of mean linear intercept (MLI) and found enlarged alveoli in adult CPEB2-KO lungs (Additional file 1: Figure S3a, $P<0.01$ ), which is the typical morphological change in emphysematous lungs. Clinically, the marked enlargement of alveolar spaces is the hallmark of BPD and chronic obstructive pulmonary disease (COPD). However, no reduction in populations of type I AECs (AECIs) and AECIIs was observed (Additional file 1: Figure S3b). Although the number of infiltrating leukocytes in the bronchoalveolar lavage fluid (BALF) from CPEB2-KO mice were moderately increased (Additional file 1: Figure S3c, $P<0.01)$, there were no signs of inflammation because BALF cells contained only resident macrophages, and the mRNA levels of pro-inflammatory cytokines (interleukin-1 $\beta$ and interferon- $\gamma$ ) and metalloproteinase- 9 were normal (Additional file 1: Figure S3d). Thus, the CPEB2-KO mouse emphysematous phenotype is unlikely caused by chronic inflammation-induced alveolar obstruction and is more reminiscent of BPD.

To examine whether the alveolar structure is developmentally affected by CPEB2 deficiency, we analyzed the histology and MLI of CPEB2-WT and -KO lungs at different ages. Although CPEB2-KO lungs appeared normal at birth (P0), they showed enlarged air spaces from P3 to P60 with substantial simplification of alveolar structure (Fig. 2a, $P<0.01$ ), which supports that impaired lung function and altered alveolar structure are due to developmental defects during the early postnatal age.

\section{CPEB2 deficiency reduces cell proliferation and MYF population at the alveolar stage of lung development} Because the imbalance between alveolar cell proliferation and apoptosis during lung development accounts for emphysema-like phenotypes in many gene-ablated mouse models [39-45], we examined both scenarios in CPEB2-WT and -KO lungs at the alveolar stage [i.e., after birth to P20 in rodents [46]], to adulthood (P60) by detecting the incorporation of 5-bromo-2'-deoxy-uridine (BrdU) and active caspase-3, respectively. To normalize unequivalent alveolar airspace in WT and KO lungs, the cell density was calculated by dividing cell numbers with DAPI-positive (nuclei) area. In CPEB2-WT alveoli, BrdU-positive $\left(\mathrm{BrdU}^{+}\right)$proliferating cells gradually increased to peak at P7 and decreased to a barely detectable level at P21 and P60 (Fig. 2b). Although a similar proliferation curve was observed in CPEB2-KO alveoli, the number of $\mathrm{BrdU}^{+}$cells was lower from P1 to P7 (Fig. 2b). Notably, proliferating cells were slightly more in CPEB2-KO lungs than WT lungs at P14. By contrast, CPEB2 depletion did not affect pulmonary apoptosis because of a similar number of active caspase 3-positive cells (Fig. 2c).

Proliferation and differentiation of alveolar cells precede alveolar septation [2]. Despite CPEB2 detected in the lung by western blot analysis [23], we could not obtain a specific CPEB2-immunostained signal in pulmonary sections after trying different antigen-retrieval and staining protocols. Nevertheless, the single cell RNA sequencing results from LungGENS [47] indicated the presence of CPEB2 mRNA in all 3 major alveolar cells, AECIs, AECIIs and MYFs, for the formation of secondary septa (Additional file 1: Figure S4a), so we first determined which alveolar cell type was mostly affected by CPEB2 depletion. AECIs line the alveoli to construct airexchanging units and AECIIs secrete surfactants to prevent alveolar collapse during expiration $[2,20,48]$. The distribution and number of caveolin-1-positive $\left(\mathrm{Cav1}^{+}\right)$ AECIs (Fig. 3a, a') and pro-surfactant-C-positive $\left(\right.$ SFTPC $\left.^{+}\right)$AECIIs (Fig. 3b, b') appeared normal in P3 CPEB2-KO lungs, which supports our observation in adult CPEB2-KO lungs (Additional file 1: Figure S3b). Moreover, the unaltered protein levels of Cav1 and SFTPC in P1 and P3 CPEB2-KO lungs (Additional file 1: Figure S4b) also reconfirmed the unaffected AECI and AECII populations in the absence of CPEB2. Due to the extended morphology of AECIs, a nuclear marker of AECIs, homeodomain-only protein $\mathrm{x}$ (Hopx) [49], was also examined. We observed not all $\mathrm{Cav}^{+}$AECIs expressing Hopx but the populations of Hopx-positive $\left(\mathrm{Hopx}^{+}\right)$AECIs in P3 WT and KO lungs were comparable (Additional file 1: Figure S4c, c'). By contrast, the number of $\alpha \mathrm{SMA}^{+}$MYFs was significantly reduced (Fig. 3c, c', $P<0.05$ ), so we further analyzed the number of $\alpha \mathrm{SMA}^{+}$cells in WT and KO lungs through the alveolar stage and adulthood. Regardless of genotype, the $\alpha \mathrm{SMA}^{+} \mathrm{MYF}$ population was transiently expanded from $\mathrm{P} 1$ to $\mathrm{P} 10$ and then vanished to almost undetectable at P21 and P60 (Fig. 3d). In CPEB2-KO lungs, the $\alpha \mathrm{SMA}^{+}$ MYF population was reduced at P3, P7 and P10 but increased at P14 as compared with WT lungs.

\section{Mislocalized MYFs and disorganized elastic fibers in CPEB2-KO lung}

Migration of alveolar MYFs to the tips of growing septa during alveologenesis is essential for proper formation of elastin scaffold $[5,18,19,37]$. Most $\alpha \mathrm{SMA}^{+}$MYFs already migrated to the tips of secondary septa in P7 WT lungs (Fig. 4a, arrowheads) but were trapped within the walls of enlarged alveoli in CPEB2-KO lungs (Fig. 4a, arrows). Thus, we wondered whether CPEB2-deficient 

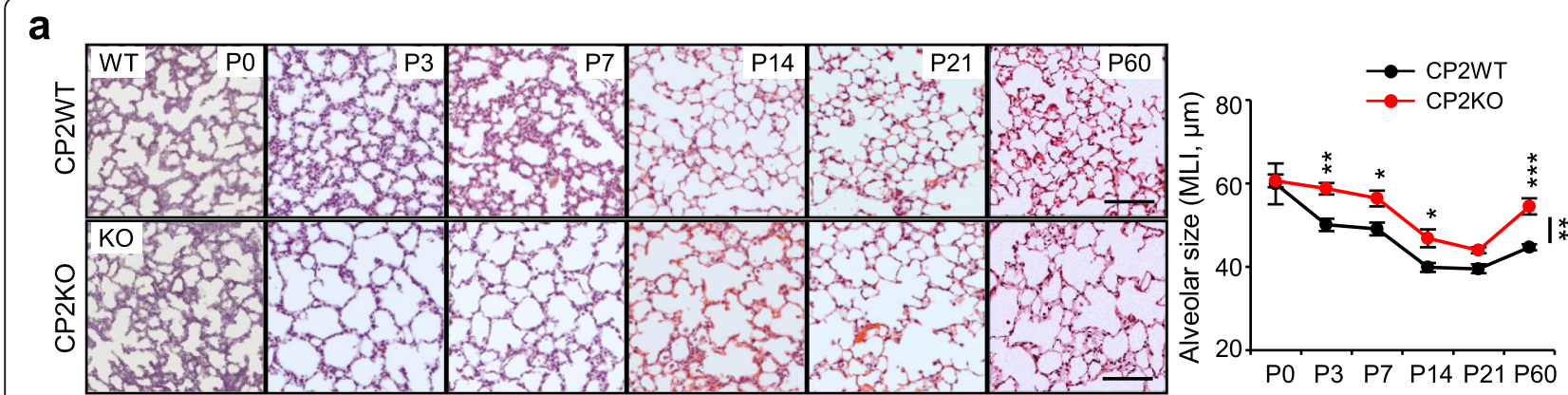

b
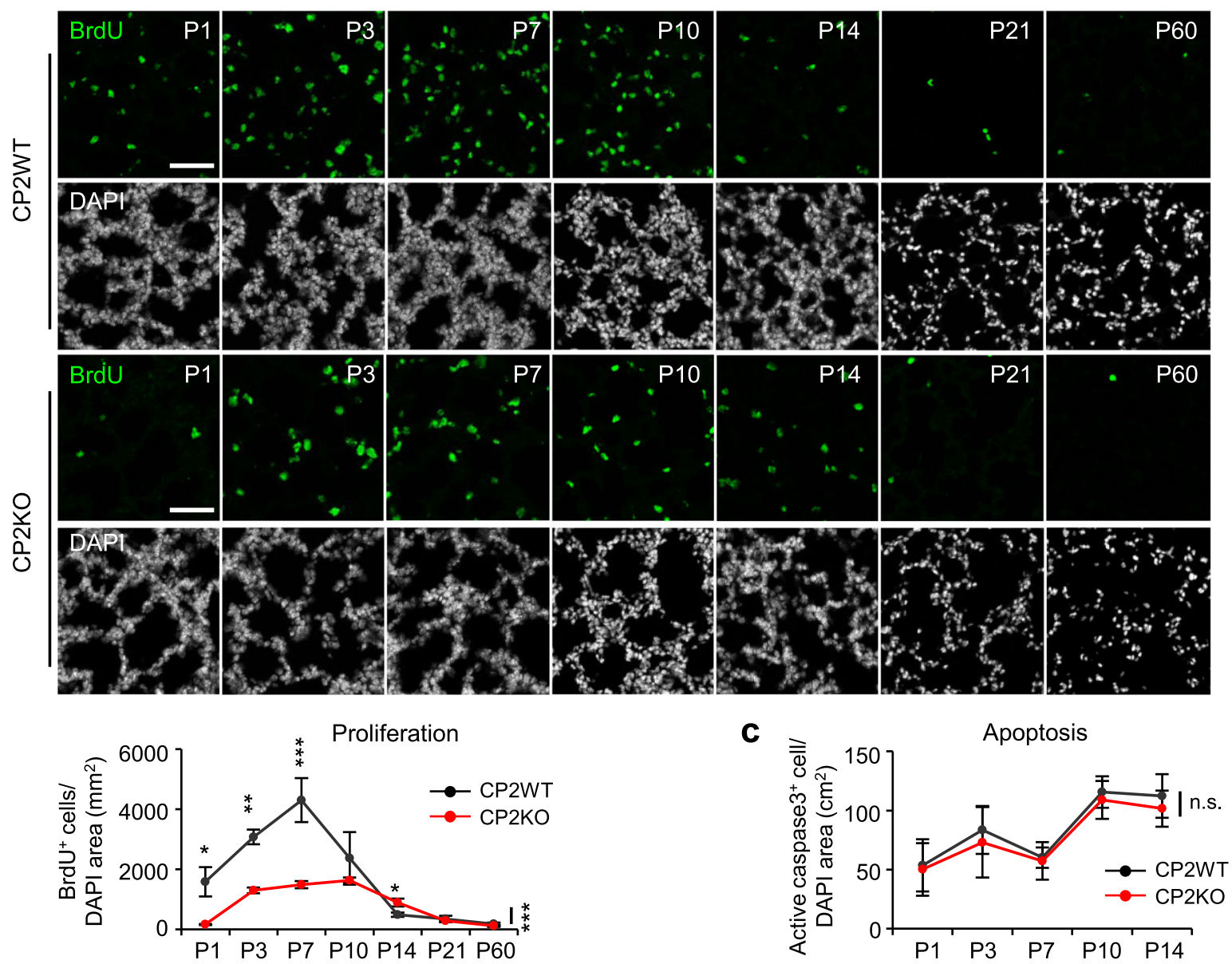

Fig. 2 Defective alveolarization and cell proliferation in developing CPEB2-KO lungs. a Representative images of H\&E-stained lung sections used to measure alveolar size in CP2WT and CP2KO mice at different postnatal ages ( $n=5$ mice per group at each time). MLI, mean linear intercept. Scales, $200 \mu \mathrm{m}$. b The number of BrdU-positive $\left(\mathrm{BrdU}^{+}\right)$proliferating cells in CP2WT and CP2KO lungs at the denoted postnatal days. Representative images of BrdU- and DAPI-labeled pulmonary sections and quantification. Scales, 50 um. c Apoptosis in CP2WT and CP2KO lungs at the alveolar stage, determined by number of active caspase ${ }^{+}$cells. Data are mean \pm s.e.m. $(n=5$ mice per group at each time), n.s. not significant, ${ }^{*} P<0.05,{ }^{*} P<0.01$, and ${ }^{* * *} P<0.001$, compared with CP2WT mice by two-way ANOVA and Bonferroni post-hoc test

MYFs showed defective migration contributing to their entrapment in alveolar walls. To measure migratory rate and polarity of MYFs, we used a wound-healing assay in cultured MYFs isolated from P10 CPEB2-WT and -KO lungs. We used immunoblotting (Additional file 1: Figure S5a) and immunofluorescence staining (Additional file 1: Figure S5b) for CPEB2 to confirm its expression in primary MYFs. Moreover, CPEB2 deficiency did not affect $\alpha$ SMA protein level (Additional file 1: Figure S5a), so the number of $\alpha \mathrm{SMA}^{+}$MYFs was indeed reduced in CPEB2-KO lungs (Fig. 3d). A scratch wound was inflicted on confluent MYFs and then examined for cell repopulation and orientation. When cells at the wounded edge move toward the scratched area, their 


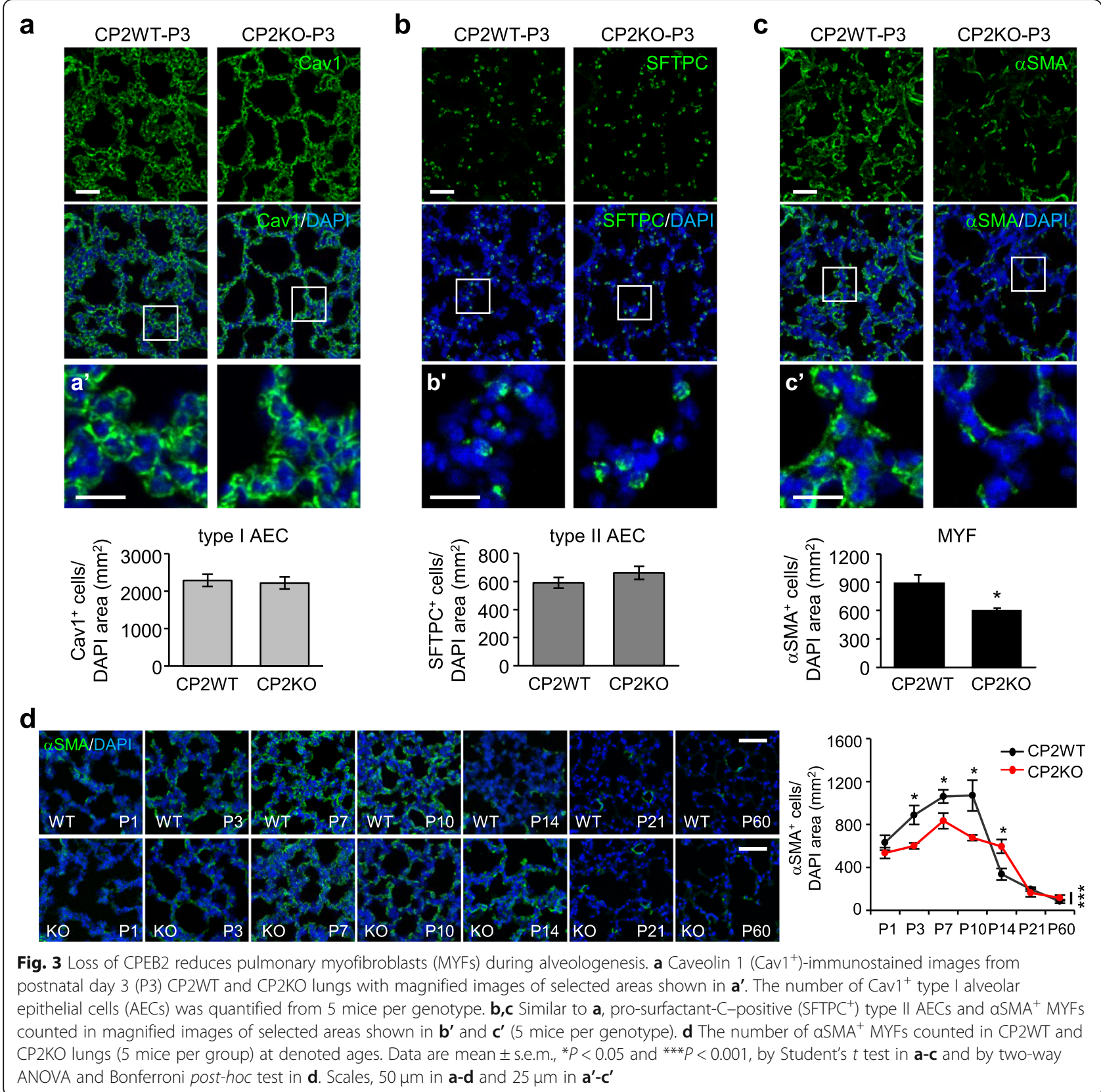

Golgi organelles should position on the leading side of nuclei [50]. Although the migration rates of WT and KO MYFs were identical (Additional file 1: Figure S5c), the polarity of MYFs was significantly affected by CPEB2 depletion (Additional file 1: Figure S5d, $P<0.05)$. For approximately $65 \%$ of WT MYFs, the Golgi apparatus was oriented within a $60^{\circ}$ angle perpendicular to the migratory direction, but the percentage dropped to $\sim 52 \%$ for CPEB2-KO MYFs. Hence, CPEB2 may control the intrinsic polarity of MYFs that may contribute in part to MYF migration during alveolarization.
Reduced population (Fig. 3d) and improper localization (Fig. 4a) of mature $\alpha_{S_{M A}}^{+}$MYFs should affect alveolar elastin deposition, so we characterized the density, morphology and localization of elastic fibers in CPEB2-WT and - KO lungs at different postnatal ages (Fig. 4b). At the alveolar phase of development in WT lungs, elastic fibers were deposited along respiratory saccules and then concentrated at the tips of septa (Fig. 4b, arrowheads). By contrast, in CPEB2-KO lungs from P7 to P60, elastic fibers accumulated along alveolar walls (Fig. 4b, arrows) and were less concentrated at the tips of septa (Fig. 4c, $P<0.001$ ). Although the density of 


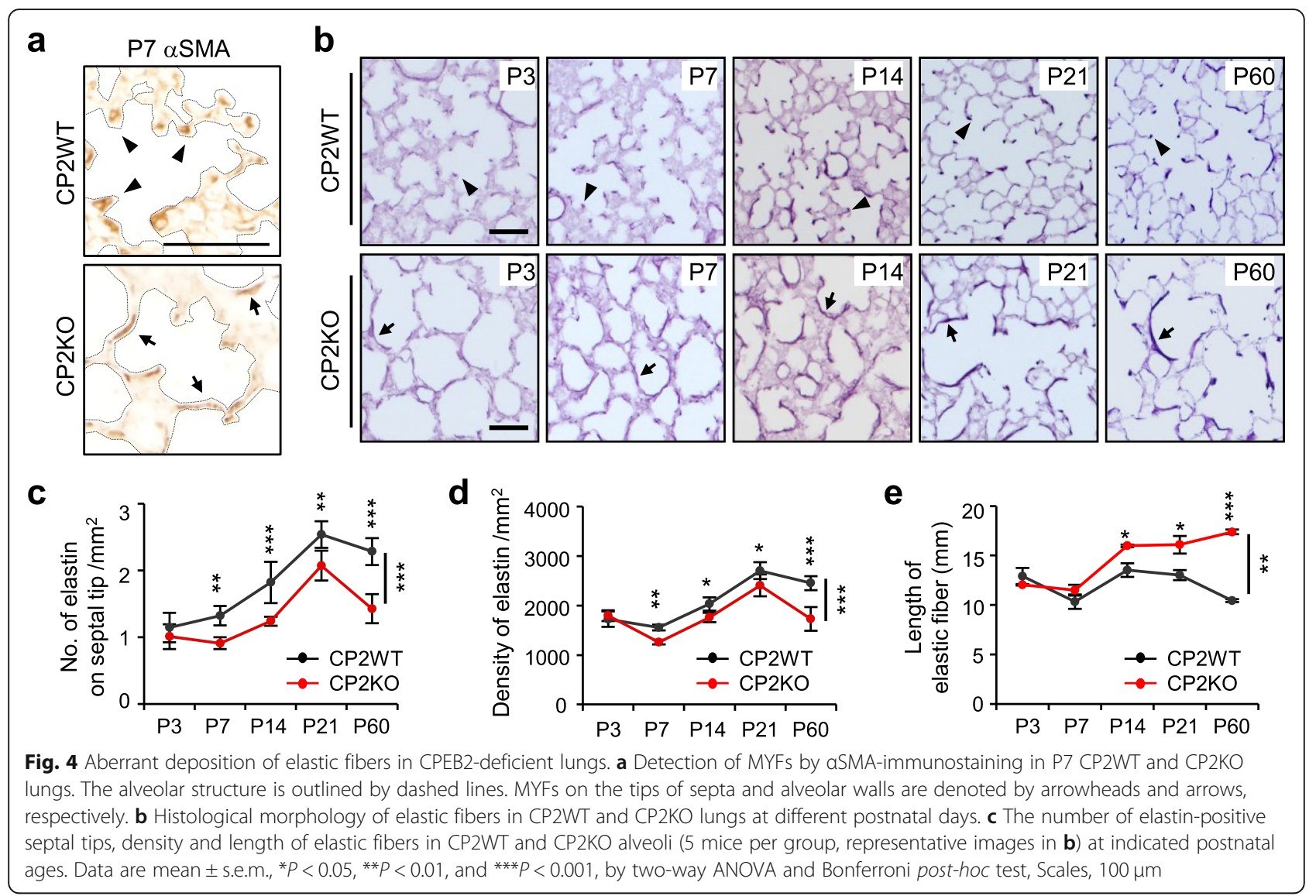

elastic fibers was diminished in CPEB2-KO lungs from P7 to P60 (Fig. 4d, $P<0.001$ ), the elongated fibers along septa were longer on average in CPEB2-KO lungs than WT lungs from P14 to P60 (Fig. 4e, $P<0.01$ ). Together, CPEB2 deficiency resulted in reduced and mislocalized MYFs during pulmonary alveologenesis, thereby contributing to abnormal deposition of elastic fibers and emphysema-like dysfunction.

\section{Decreased proliferation of PDGFRa-positive progenitors in CPEB2-KO lung}

Because of reduced alveolar cell proliferation (Fig. 2b) and MYF population (Fig. 3d), PDGF signaling for alveologenesis may be defective in the CPEB2-KO lung to affect the proliferation of PDGFR $\alpha$-expressing $\left(\mathrm{PDGFR \alpha}^{+}\right)$MYF progenitors. Using MYFs cultured from lungs at different postnatal ages, we found that CPEB2 and PDGFR $\alpha$ levels changed in parallel. Both proteins gradually increased from P1 to P7 and decreased significantly after P14 (Additional file 1: Figure S6). Thus, we analyzed the pools of PDGFR $\alpha^{+}$cells (Fig. 5a) and proliferating PDGFR $\alpha^{+}$progenitors (BrdU ${ }^{+}$PDGFR $\alpha^{+}$, Fig. 5b). From P3 to P10, CPEB2 deficiency significantly decreased the number of both PDGFR $^{+}$cells (Fig. 5a', $P<0.001$ ) and BrdU $^{+}$PDGFR $\alpha^{+}$ progenitors (Fig. 5b', $P<0.001$ ). Because not all proliferating PDGFR $\alpha^{+}$progenitors are MYF precursor cells, we also simultaneously detected $\alpha$ SMA. Cells containing triple positive signals $\left(\mathrm{BrdU}^{+} \mathrm{PDGFR} \alpha^{+} \alpha \mathrm{SMA}^{+}\right)$are considered MYF progenitors (magnified images and counting criteria in Additional file 1: Figure S2), a portion of proliferating PDGFR $\alpha^{+}$cells committed to become MYFs, and were diminished in number in P3-P10 lungs (Fig. 5b", $P<0.001$ ). To confirm this finding not from sectioning artifacts, we used 3-dimensional reconstructed images [5] to examine P10 WT and KO lungs and observed evident reduction of $\mathrm{BrdU}^{+} \mathrm{PDG}$ $\mathrm{FR}^{+} \alpha \mathrm{SMA}^{+}$cells around CPEB2-KO alveoli (Fig. 5c, Additional file 1: Figure S7, arrows).

\section{CPEB2 binds to and activates PDGFRa mRNA translation}

PDGF-A signaling is essential for lung MYF development and alveologenesis [19]. Although we tried to detect the ligand PDGF-A by using 3 different antibodies, we found no consistent staining patterns on immunohistochemistry or immunoblotting assay. In contrast, the PDGFR $\alpha$ signal of correct molecular weight on western blots was significantly reduced in P3 CPEB2-KO lung lysates and more evident in P10 lysates (Fig. 6a), which agrees with the immunostaining result (Fig. 5a,a'). In 


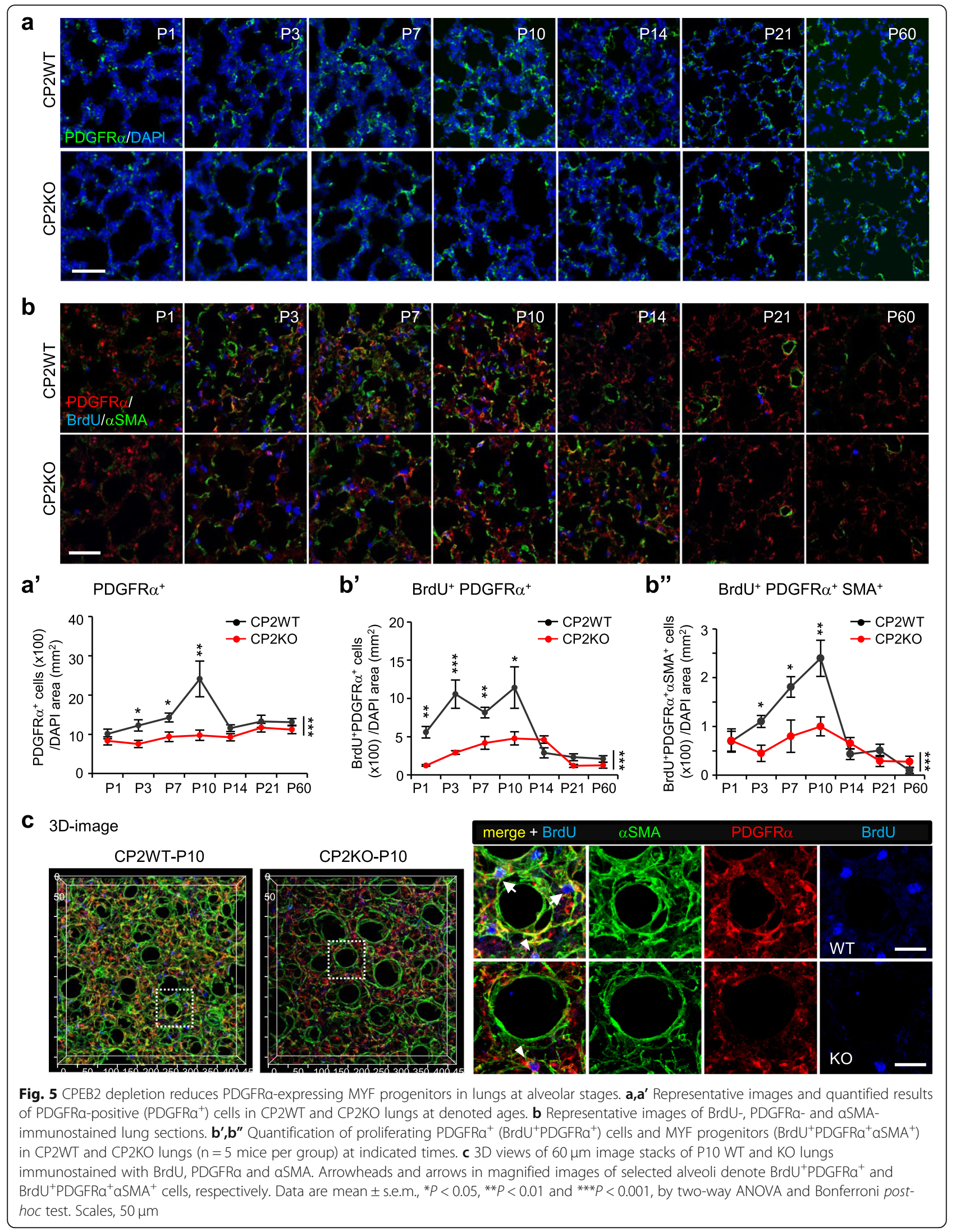


contrast, the PDGFR $\alpha$ mRNA levels in P0 and P3 lungs did not differ significantly between WT and $\mathrm{KO}$ groups (Additional file 1: Figure S8), so CPEB2 may regulate the PDGFR $\alpha$ protein level. Although the population of AECIIs remained unaltered in CPEB2-KO mice (Fig. 3b), CPEB2 may affect PDGF-A synthesis. Alternatively, CPEB2 may regulate PDGFR $\alpha$ synthesis in MYF progenitors to support proliferation. Both 3'-untranslated regions (UTRs) of PDGFR $\alpha$ and PDGF-A mRNAs contain canonical CPEB-binding elements (CPE, UUUUA $\left.{ }_{1-2} \mathrm{U}\right)$, so we tested whether CPEB2 could associate with them in the developing lung by RNA immunoprecipitation. Using P3 lung lysates, we found that CPEB2 bound to PDGFR $\alpha$ but not PDGF-A mRNA (Fig. 6b). The 3'-UTR of PDGFR $\alpha$ mRNA contains 3 CPEs (UUUUAU) located just upstream of the poly(A) signal (AAUAAA, Fig. 6c). To investigate whether CPEB2 activates the translation of PDGFR $\alpha$ mRNA via its 3'-UTR, we used dual luciferase reporter assay with firefly luciferase (FLuc) appended with mouse PDGFR $\alpha$ 3'-UTR in HeLa cells. The Renilla luciferase (RLuc) plasmid was used to normalize the variation in transfection efficiency. Indeed, ectopically expressed CPEB2 upregulated the translation of FLuc reporter RNA appended with the full-length or 1-kb PDGFR $\alpha$ 3'-UTR, both containing 3 CPEs (Fig. 6c). However, such upregulation was abrogated when all 3 CPEs were deleted (Fig. 6c, FLuc-3'UTR $\triangle \mathrm{CPE}$ ), so CPEB2 activates PDGFR $\alpha$ mRNA translation via binding to 3 'UTR CPEs.

\section{CPEB2 is required for PDGFRa signaling-induced MYF proliferation}

Some PDGFR $\alpha^{+}$cells (Fig. 5a'), particularly those with proliferating ability (Fig. 5b') and already expressing aSMA to become MYFs (Fig. 5b"), were reduced in number in developing CPEB2-deficient lungs, so we assessed whether the reduced PDGFR $\alpha$ expression was intrinsic in CPEB2-KO MYFs and MYF progenitors. We cultured primary MYFs from CPEB2-WT and -KO lungs and examined the protein and RNA levels of PDGFR $\alpha$. As expected, only the protein level (Fig. 6d) but not RNA level (Fig. 6e) of PDGFR $\alpha$ was decreased in CPEB2-KO MYF cultures. Importantly, the amount of PDGFR $\alpha$ protein in CPEB2-KO MYFs could be rescued by ectopic expression of myc-CPEB2 (Fig. 6f). We further examined PDGF-A-induced cell cycle re-entry of G0/G1arrested MYFs by Ki67-immunostaining and found that the reduced number of $\mathrm{Ki}^{+} 7^{+} \alpha \mathrm{SMA}^{+}$cells in CPEB2-KO MYF culture could be rescued by ectopic expression of myc-CPEB2 (Fig. $6 \mathrm{~g}$ and representative images in Additional File 1: Figure S9). Together, these data indicate that CPEB2 promotes translation of PDGFR $\alpha$ mRNA in MYF progenitors for cell-autonomous proliferation.

\section{Oxidative stress decreases CPEB2 level accompanied by} PDGFRa downregulation

Loss of CPEB2 results in insufficient PDGFR $\alpha$ protein synthesis in MYF cultures (Fig. 6d,f), a reduced MYF population (Fig. 3d) and proliferation (Fig. 6g), and abnormal elastin deposition (Fig. 4b) for development of BPD-like phenotypes. Similarly, defective pulmonary PDGFR signaling is a key feature of human BPD and hyperoxia-treated neonatal rodents [22]. Because CPEB2-activated PDGFR $\alpha$ mRNA translation is important for alveologenesis, we wondered whether humans at risk of BPD may show reduced CPEB2 level. We analyzed a Gene Expression Omnibus (GEO) repository dataset (GSE8586), which contains the transcriptomic profiles of umbilical cord tissues collected from human infants born at $<28$ weeks' gestation, who later showed BPD or not [31]; the mRNA level of CPEB2 but not PDGFR $\alpha$ was significantly decreased in BPD infants (Fig. 7a, $P<0.05)$. In the other study (GSE99633), newborn rats under $95 \%$ hyperoxia for 10 days were sacrificed at P12 to isolate lung CD146 ${ }^{+}$MSCs [32]. Because these $\mathrm{CD} 146^{+}$MSCs also contain a PDGFR $\alpha$-expressing MYF lineage during the alveolar stage of lung development [4], we analyzed this dataset and found a significant reduction in CPEB2 and PDGFR $\alpha$ mRNA levels in hyperoxia-exposed pulmonary MSCs (Fig. 7b, $P<0.001$ ). Thus, we hypothesized that hyperoxia exposure during alveologenesis in humans and rodents may downregulate PDGFR $\alpha$ protein synthesis, in part by impairing CPEB2activated translation. Hyperoxia exposure was reported to increase $\mathrm{H}_{2} \mathrm{O}_{2}$ production in lung and brain $[51,52]$, so we tested the above hypothesis by treating WT and CPEB2-KO MYF cultures with $100 \mu \mathrm{M} \quad \mathrm{H}_{2} \mathrm{O}_{2}$, a hyperoxia-mimetic condition, to evaluate $\mathrm{CPEB} 2$ and PDGFR $\alpha$ expression. $\mathrm{H}_{2} \mathrm{O}_{2}$-reduced PDGFR $\alpha$ protein level was evident in only CPEB2-WT MYF culture (Fig. 7c). Although PDGFR $\alpha$ was downregulated in CPEB2-KO MYFs under normoxia, it was not further diminished by $\mathrm{H}_{2} \mathrm{O}_{2}$ (Fig. 7c). Of note, CPEB2 level was also decreased in $\mathrm{H}_{2} \mathrm{O}_{2}$-treated MYFs (Fig. 7c). Moreover, the protein levels of CPEB2 and PDGFR $\alpha$ were positively correlated after $\mathrm{H}_{2} \mathrm{O}_{2}$ treatment (Fig. 7d). Along with our previous finding that bronchoconstriction-associated respiratory defect is caused by elevated choline acetyltransferase mRNA translation in dorsal motor nucleus of the vagus [23], the present study identified that CPEB2 in MYFs and MYF progenitors appears to activate PDGFR $\alpha$ mRNA translation. Together, double-hit defects in both parasympathetic transmission and pulmonary alveologenesis affect neonatal survival in global CPEB2-KO mice (Fig. 7e).

\section{Discussion}

Neonatal lethality in CPEB2-KO mice first revealed the regulatory role of $\mathrm{CPEB} 2$ in respiration. Although 


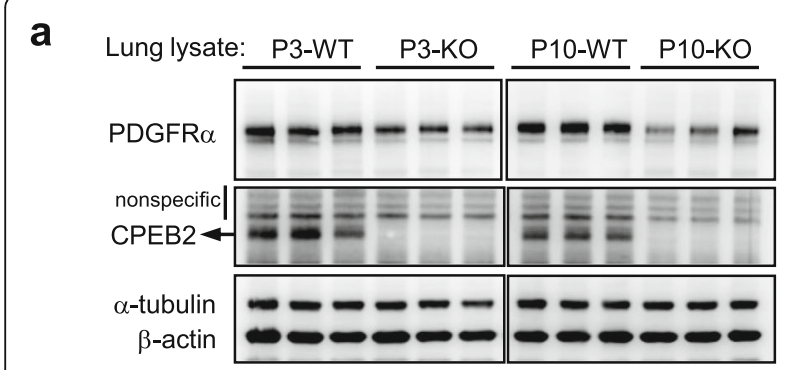

b RNA-IP

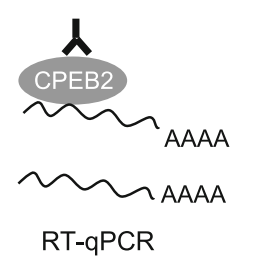

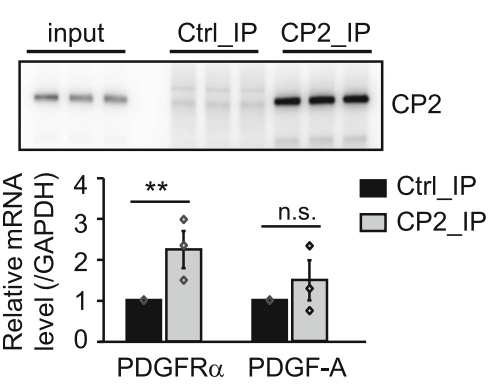

C Reporter assay

\begin{tabular}{|l|l|} 
firefly luciferase & various PDGFR $\alpha$ \\
$3^{\prime}-$ UTR
\end{tabular}

PDGFR $\alpha$ 3'UTR (3104bp)

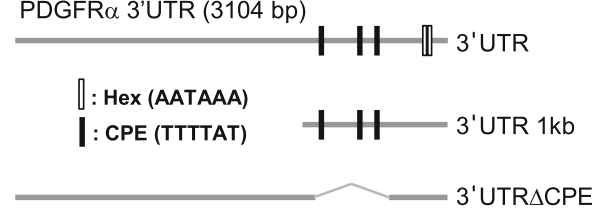

d
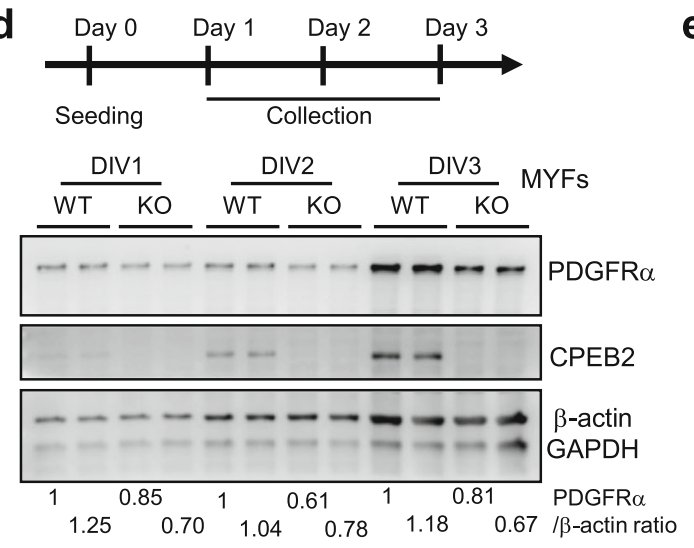

g

cell cycle re-entry: Ki67 expression

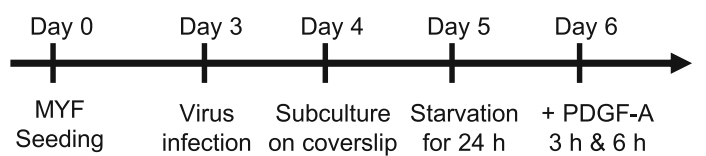

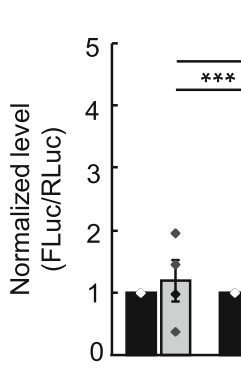

Fluc (1)

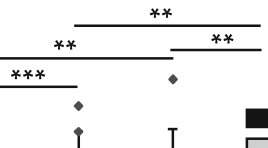

myc

$\square$ myc-CP2

(2) FLuc-PDGFR $\alpha$ 3'UTR

(3) FLuc-PDGFR $\alpha$ 3'UTR $1 \mathrm{~kb}$

(4) FLuc-PDGFR $\alpha$ 3'UTR $\triangle \mathrm{CPE}$ e

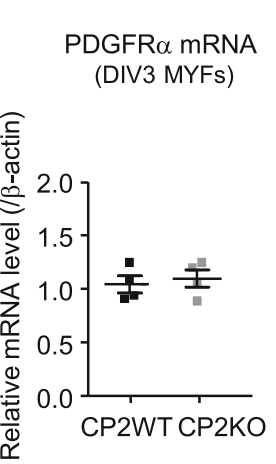

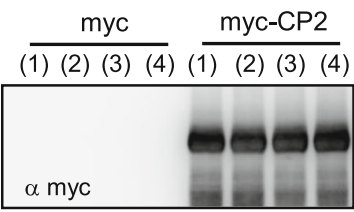

(3)

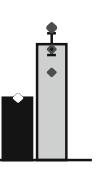

(4)

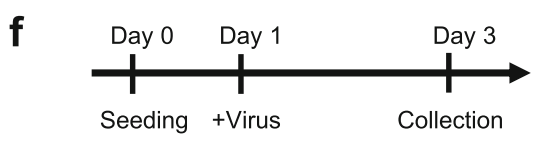

$\begin{array}{ll}\text { MYF: } & \text { Het } \\ \text { Virus: } & \text { WT } \\ \text { GFP } & \text { KO } \\ \text { myc-CP2 }\end{array}$

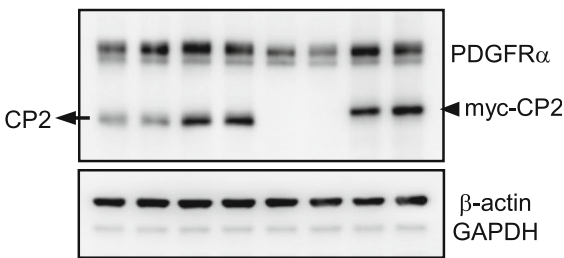

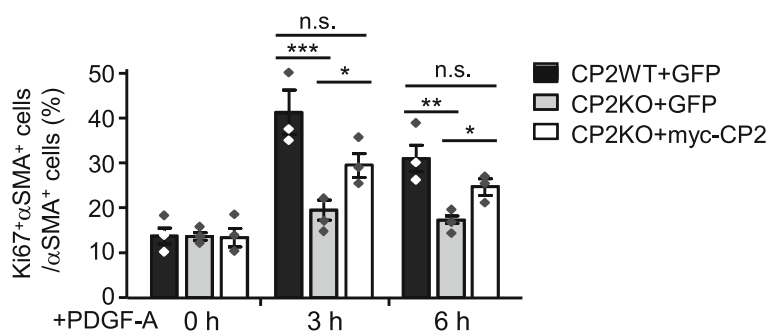

Fig. 6 CPEB2 binds to and promotes PDGFRa mRNA translation. a Western blot analysis of PDGFRa protein levels in P3 and P10 lungs from CP2WT and CP2KO mice ( $n=3$ mice per group). $\mathbf{b}$ RNA immunoprecipitation (RNA-IP). P10 lung lysates were precipitated with control (Ctrl) or CPEB2 (CP2) IgG. RT-qPCR of PDGFRa and PDGF-A mRNA levels in immunoprecipitates expressed as relative ratio to the non-target control GAPDH. Data are mean \pm s.e.m. from 3 independent experiments. c Dual luciferase reporter assay. Three CPEs and hexanucleotide (Hex) in the 3'UTR of mouse PDGFRa mRNA are marked. The reporter plasmids, one of FLuc constructs and RLuc, were co-transfected with the plasmid expressing myc-tag or myc-CPEB2 (myc-CP2) into HeLa cells. Analysis of FLuc and RLuc activity and the expression level of myc-CP2. Data are mean \pm s.e.m. from 4 independent experiments. d Primary MYF cultures from P10 lungs were harvested at 1, 2 and 3 days in vitro (DIV) for immunoblotting. e Similar to $\mathbf{d}$, except DIV3 MYF cultures were harvested for RT-qPCR of PDGFRa mRNA level relative to GAPDH. Data are mean \pm s.e.m. from 4 independent cultures. $\mathbf{f}$ Similar to $\mathbf{d}$, except DIV1 CP2WT and CP2KO MYFs were infected with lentiviruses expressing GFP or myc-CP2 and harvested at DIV3 for immunoblotting. Het: Cpeb2 ${ }^{+/-}$MYFs. d,f Protein lysates were from 2 independent cultures. g PDGF-Ainduced Ki67 expression in serum-starved MYFs. Lentivirus-infected CP2WT and CP2KO MYFs were starved in 0.5\% serum for $24 \mathrm{~h}$ and then treated with PDGF-A for the indicated time, followed by labeling of DAPI, Ki67 and aSMA. Data are mean \pm s.e.m. from 3 independent experiments. n.s. not significant, ${ }^{*} P<0.05,{ }^{*} P<0.01$ and ${ }^{* * *} P<0.001$, by Student's $t$ test in $\mathbf{b}$, one-way ANOVA in $\mathbf{c}$ and two-way ANOVA in $\mathbf{g}$ 


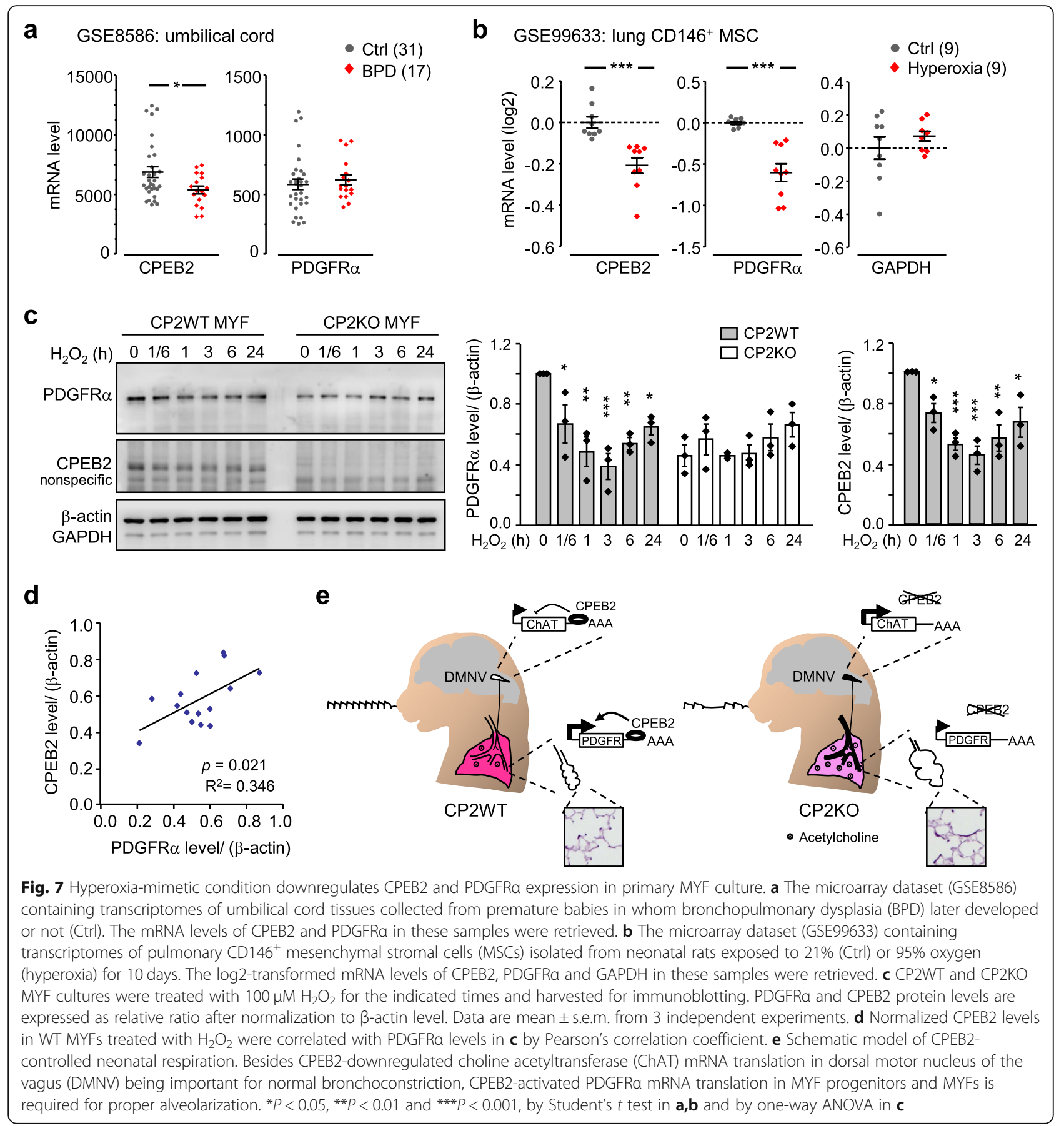

specific ablation of Cpeb2 in cholinergic neurons recapitulates obstructive airway-associated apnea, the degree of severity is much reduced to cause death [23], so we initiated our investigation to search for other respiratory anomalies in global CPEB2-KO mice. Emphysema-like phenotypes in adult CPEB2-deficient mice reminded us of two hypoalveolarization diseases, BPD and COPD. BPD results from abnormal lung development, whereas COPD represents the destruction of an established alveolar structure by chronic inflammation. Because the alveolar structure changes, including alveolar size, elastic fiber deposition and secondary septum formation, take place within the 1st postnatal week in CPEB2-KO mice, the depletion of CPEB2 leads to abnormal lung manifestations reminiscent of human BPD. Lung organogenesis in both humans and mice proceeds through 5 morphogenesis phases- embryonic, pseudoglandular, canalicular, saccular and alveolar - to establish a sophisticated alveolus and microcapillary-coupled network for efficient exchange of oxygen and carbon dioxide [46]. Most BPD 
cases develop in preterm babies of $<28$ weeks' gestation, whose lungs are still at the saccular stage of development and are too immature to support autonomous breathing. Thus, mechanical ventilation with the amount of oxygen higher than normoxia is used to support their survival, but the pressure and excess oxygen can induce BPD manifestation in only some infants, which suggests that genetics also determines susceptibility to BPD. By contrast, CPEB2-deficiency-induced emphysematous phenotypes result from diminished PDGFR $\alpha$ expression in MYF progenitors to impair the alveolar phase of lung development. We found that oxidative stress could downregulate CPEB2 expression in MSCs and MYF culture (Fig. 7b and c), so defective translation together with a reduced PDGFR $\alpha$ mRNA level further aggravates the insufficiency of PDGFR $\alpha$ signaling. Therefore, the loss of CPEB2 function, due to genetic mutations or oxidative stress insult, may possibly be a risk factor for human BPD.

The critical role of PDGF/PDGFR signaling in alveolar development was first discovered in lungs of PDGF-Anull mice with reduced secondary septa and enlarged alveolar sacs $[18,19]$. Specific depletion of PDGF-A in AECIIs during the alveolar phase of lung development is sufficient to impair alveolarization. PDGF-A released from AECIIs is required to support the proliferation of Pdgfra promoter-driven GFP-expressing cells, including MYFs and lipofibroblasts. Moreover, this study also found increased proliferation and number of AECIIs [53]. Mice with mesenchyme-specific depletion of PDGFR $\alpha$ also showed impaired alveologenesis and disorganized alveolar elastic fibers [5]. Together, both studies demonstrated that PDGF-A and PDGFR $\alpha$ signaling from AECIIs to mesenchymal fibroblasts is necessary for alveologenesis. Because CPEB2 did not bind to PDGF-A mRNA (Fig. 6b), defective alveolar development in CPEB2-KO mice primarily resulted from reduced PDGFR $\alpha$ signaling in MYF progenitors (Fig. 6f,g). Notably, we found an opposite increase of proliferating cells (Fig. $2 \mathrm{~b}$ ) and $\alpha \mathrm{SMA}^{+}$MYFs (Fig. $3 \mathrm{~d}$ ) in P14 CPEB2-KO lungs, both similarly reported in PDGFR signaling-deficient rodents $[5,21]$. In rats treated with the PDGFR $\alpha$ and $\beta$ antagonist imatinib from P1 to P7, shortterm blockade of PDGFR signaling induced permanent failure of alveologenesis, including reduced number of $\mathrm{BrdU}^{+}$proliferating cells at P8 and P28, enlarged distal air sacs and abnormal elastin deposition [21]. Notably, a transient increase in $\mathrm{BrdU}^{+}$cells in imatinib-treated lungs at P14 was reported, but such an increase was mostly contributed by vascular endothelial cells [21]. The other study used hyperoxia-exposed mice to mimic alveolar defects in human BPD and detected alveolar $\alpha$ SMA in hyperoxiatreated lungs at P15 when normoxia-exposed alveoli no longer contain $\alpha \mathrm{SMA}^{+}$MYFs [5], similar to what we observed in Fig. 3d. Thus, both CPEB2 deficiency and hyperoxia exposure reduce pulmonary PDGFR signaling, leading to delayed maturation of $\alpha \mathrm{SMA}^{+}$MYFs whose proliferation in WT mice has already stopped at P14.

The expression of PDGFR $\alpha$ is widely controlled; however, most studies focused on transcriptional regulation or mRNA stabilization. For example, Gli1 and peroxideinducible Ets-1 have been reported to bind to the Pdgfra promoter and activate $P d g f r \alpha$ transcription [54, 55]. Tumor necrosis factor- $\alpha$ inhibits $P d g f r \alpha$ transcription depending on cFos-YY1 complex formation and histone deacetylase activity [56]. Besides transcriptional control, PDGFR $\alpha$ mRNA level in hypoxia-exposed pulmonary artery smooth muscle cells could be downregulated by microRNA-34a (miR-34a) to impair cell proliferation and migration [57]. Interestingly, a recent study reported that miR-34a level is markedly elevated in a hyperoxiabased BPD mouse model to impair PDGFR $\alpha$ expression and MYF proliferation [58]. Antagonizing miR-34a function could ameliorate hyperoxia-induced hypoalveolarization [58]. Together, PDGFR $\alpha$ synthesis can be regulated at the posttranscriptional level in response to various oxidative stresses. In addition, another relevant study in rat pulmonary MYFs showed that interleukin $1 \beta$-induced stabilization of PDGFR $\alpha$ mRNA is sensitive to the protein synthesis inhibitor cycloheximide but the nature of those de novo synthesized proteins involved in stabilizing PDGFR $\alpha$ mRNA has not been identified [59].

The limitation of using global CPEB2-KO mice for the study is whether other pulmonary cell types may also contribute to defective alveolarization cannot be excluded. Nevertheless, the results from MYF culture study (Fig. 6f,g) clearly demonstrated that CPEB2-activated PDGFR $\alpha$ expression contributes to MYF proliferation, which is necessary to support alveologenesis. Because PDGFR $\alpha$ signaling also regulates pathological fibrosis in injured organs and tumorigenesis $[10,16,60-62]$, whether CPEB2-mediated translation controls PDGFR $\alpha$ signaling under pathological conditions remains an open question. Moreover, analysis of the two GSE datasets suggested that decreased CPEB2 mRNA level is associated with BPD in infants (Fig. 7a) and induced by hyperoxia in pulmonary MSCs. Whether deficient CPEB2controlled translation contributes to pulmonary diseases requires further clinical investigation. In summary, translational upregulation of PDGFR $\alpha$ by CPEB2 is crucial for constructing functional alveoli at the final stage of lung development to support life-long respiration.

\section{Conclusions}

The present study identified a novel cell-autonomous mechanism by which CPEB2 upregulates PDGFR $\alpha$ mRNA translation to drive the proliferation of pulmonary MYFs and lung maturation. Impaired CPEB2regulated translation during alveolar phase of lung development may be at the risk of BPD. 


\section{Supplementary information}

Supplementary information accompanies this paper at https://doi.org/10. 1186/s12929-020-00643-0.

Additional file 1. Supplementary information is available online.

\section{Abbreviations}

AECl: Type I alveolar epithelial cell; AECII: Type II alveolar epithelial cell; BALF: Bronchoalveolar lavage fluid; BPD: Bronchopulmonary dysplasia; BrdU: 5-bromo-2'-deoxy-uridine; CAV1: Caveolin-1; COPD: Chronic obstructive pulmonary disease; CPEB2: Cytoplasmic polyadenylation element-binding protein; DAPI: 4',6-diamidino-2-phenylindole; eEF2: Eukaryotic translation elongation factor 2; FBS: Fetal bovine serum; GAPDH: Glyceraldehyde-3phosphate dehydrogenase; Hopx: Homeodomain-only protein x; KO: Knockout; MLI: Mean linear intercept; MSC: Mesenchymal stromal cell; MYF: Myofibroblast; PDGF: Platelet-derived growth factor; PDGFRa: Plateletderived growth factor receptor a; PEF: Peak expiratory flow; PIF: Peak inspiratory flow; SFTPC: Pro-surfactant-C; SMA: Smooth muscle actin; UTR: Untranslated region; WBP: Whole-body plethysmography; WT: Wild-type

\section{Acknowledgements}

We thank the Taiwan Mouse Clinic for WBP experiments, and the pathology core for tissue processing and H\&E staining. We thank Hao-Wen Chen, TzuYu Hsieh and Shin-Hui Yeh for image analysis and quantification.

\section{Authors' contributions}

Y-TL H-WC designed and conducted the experiments and analyzed data. ACYL and S-H Lin performed experiments. Y-JC and Y-SH designed and supervised the study. Y-SH co-wrote the manuscript with Y-TL and H-WC and is responsible for its content. The author(s) read and approved the final manuscript.

\section{Funding}

This work was supported by grants from the Ministry of Science and Technology of Taiwan [MoST105-2311-B-001-078-MY3 and 105-2321-B-001064 to Y.-S.H. and 105-2628-B-001-009-MY3 to Y.-J.C.]. Taiwan Mouse Clinic is funded by MoST [106-2319-B-001-004].

\section{Availability of data and materials}

The datasets used and/or analyzed during the current study are available from the corresponding author on reasonable request.

\section{Ethics approval and consent to participate}

Not applicable.

\section{Consent for publication}

Not applicable.

\section{Competing interests}

The authors declare that they have no competing interests.

\section{Author details}

${ }^{1}$ Institute of Biomedical Sciences, Academia Sinica, 128 Sec. 2, Academia Rd, Taipei 11529, Taiwan. ${ }^{2}$ Department of Physiology, School of Medicine, College of Medicine, Taipei Medical University, Taipei 11031, Taiwan. ${ }^{3}$ Graduate Institute of Medical Sciences, College of Medicine, Taipei Medical University, Taipei 11031, Taiwan.

Received: 24 November 2019 Accepted: 26 March 2020

Published online: 15 April 2020

\section{References}

1. Whitsett JA, Wert SE, Trapnell BC. Genetic disorders influencing lung formation and function at birth. Hum Mol Genet. 2004;13(2):R207-15 Spec No.

2. Warburton D, El-Hashash A, Carraro G, Tiozzo C, Sala F, Rogers O, et al. Lung organogenesis. Curr Top Dev Biol. 2010;90:73-158.

3. Chao CM, Moiseenko A, Zimmer KP, Bellusci S. Alveologenesis: key cellular players and fibroblast growth factor 10 signaling. Mol Cell Pediatr. 2016;3(1):17
4. Ntokou A, Klein F, Dontireddy D, Becker S, Bellusci S, Richardson WD, et al. Characterization of the platelet-derived growth factor receptor-alphapositive cell lineage during murine late lung development. Am J Phys Lung Cell Mol Phys. 2015;309(9):L942-58.

5. Branchfield K, Li R, Lungova V, Verheyden JM, McCulley D, Sun X. A threedimensional study of alveologenesis in mouse lung. Dev Biol. 2016;409(2):429-41.

6. Noskovicova N, Petrek M, Eickelberg O, Heinzelmann K. Platelet-derived growth factor signaling in the lung. From lung development and disease to clinical studies. Am J Respir Cell Mol Biol. 2015;52(3):263-84.

7. Funa K, Uramoto H. Regulatory mechanisms for the expression and activity of platelet-derived growth factor receptor. Acta Biochim Pol. 2003;50(3):647-58.

8. Claesson-Welsh L, Eriksson A, Westermark B, Heldin CH. CDNA cloning and expression of the human A-type platelet-derived growth factor (PDGF) receptor establishes structural similarity to the B-type PDGF receptor. Proc Natl Acad Sci U S A. 1989;86(13):4917-21.

9. Matsui T, Heidaran M, Miki T, Popescu N, La Rochelle W, Kraus M, et al. Isolation of a novel receptor cDNA establishes the existence of two PDGF receptor genes. Science. 1989;243(4892):800-4.

10. Heldin $\mathrm{CH}$. Targeting the PDGF signaling pathway in tumor treatment. Cell Commun Signal. 2013;11:97.

11. Lemmon MA, Schlessinger J. Cell signaling by receptor tyrosine kinases. Cell. 2010;141(7):1117-34

12. Zhang $H$, Bajraszewski N, Wu E, Wang H, Moseman AP, Dabora SL, et al. PDGFRs are critical for PI3K/Akt activation and negatively regulated by mTOR. J Clin Invest. 2007;117(3):730-8.

13. Raffetto JD, Vasquez R, Goodwin DG, Menzoian JO. Mitogen-activated protein kinase pathway regulates cell proliferation in venous ulcer fibroblasts. Vasc Endovasc Surg. 2006;40(1):59-66.

14. Cartel NJ, Liu J, Wang J, Post M. PDGF-BB-mediated activation of p42(MAPK) is independent of PDGF beta-receptor tyrosine phosphorylation. Am J Phys Lung Cell Mol Phys. 2001;281(4):L786-98.

15. Choudhury GG, Karamitsos C, Hernandez J, Gentilini A, Bardgette J, Abboud $\mathrm{HE}$. PI-3-kinase and MAPK regulate mesangial cell proliferation and migration in response to PDGF. Am J Phys. 1997;273(6 Pt 2):F931-8.

16. Andrae J, Gallini R, Betsholtz C. Role of platelet-derived growth factors in physiology and medicine. Genes Dev. 2008;22(10):1276-312.

17. Soriano P. The PDGF alpha receptor is required for neural crest cell development and for normal patterning of the somites. Development. 1997; 124(14):2691-700.

18. Lindahl P, Karlsson L, Hellstrom M, Gebre-Medhin S, Willetts K, Heath JK, et al. Alveogenesis failure in PDGF-A-deficient mice is coupled to lack of distal spreading of alveolar smooth muscle cell progenitors during lung development. Development. 1997;124(20):3943-53.

19. Bostrom $H$, Willetts $K$, Pekny M, Leveen $P$, Lindahl $P$, Hedstrand $H$, et al. PDGF-A signaling is a critical event in lung alveolar myofibroblast development and alveogenesis. Cell. 1996;85(6):863-73.

20. Tsao PN, Matsuoka C, Wei SC, Sato A, Sato S, Hasegawa K, et al. Epithelial notch signaling regulates lung alveolar morphogenesis and airway epithelial integrity. Proc Natl Acad Sci U S A. 2016;113(29):8242-7.

21. Lau M, Masood A, Yi M, Belcastro R, Li J, Tanswell AK. Long-term failure of alveologenesis after an early short-term exposure to a PDGF-receptor antagonist. Am J Phys Lung Cell Mol Phys. 2011;300(4):L534-47.

22. Popova AP, Bentley JK, Cui TX, Richardson MN, Linn MJ, Lei J, et al. Reduced platelet-derived growth factor receptor expression is a primary feature of human bronchopulmonary dysplasia. Am J Phys Lung Cell Mol Phys. 2014; 307(3):L231-9.

23. Lai YT, Su CK, Jiang ST, Chang YJ, Lai AC, Huang YS. Deficiency of CPEB2confined choline Acetyltransferase expression in the dorsal motor nucleus of Vagus causes Hyperactivated parasympathetic signaling-associated bronchoconstriction. J Neurosci. 2016;36(50):12661-76.

24. Chen PJ, Huang YS. CPEB2-eEF2 interaction impedes HIF-1alpha RNA translation. EMBO J. 2012;31(4):959-71.

25. Chen PJ, Weng JY, Hsu PH, Shew JY, Huang YS, Lee WH. NPGPx modulates CPEB2-controlled HIF-1alpha RNA translation in response to oxidative stress. Nucleic Acids Res. 2015;43(19):9393-404.

26. Lu WH, Yeh NH, Huang YS. CPEB2 activates GRASP1 mRNA translation and promotes AMPA receptor surface expression, long-term potentiation, and memory. Cell Rep. 2017;21(7):1783-94.

27. Chen HF, Hsu CM, Huang YS. CPEB2-dependent translation of long 3'-UTR Ucp1 mRNA promotes thermogenesis in brown adipose tissue. EMBO J. 2018;37:20. 
28. Mahadeva R, Shapiro SD. Chronic obstructive pulmonary disease * 3 : experimental animal models of pulmonary emphysema. Thorax. 2002;57(10): 908-14

29. Santos LM, de Brito Cervilha DA, Cabral LD, Garcia EK, Teixeira VP, Brito JM, et al. Bronchial responsiveness in an elastase-induced mouse model of emphysema. Respir Physiol Neurobiol. 2014;194:9-14.

30. Inoue K, Koike E, Takano H. Comprehensive analysis of elastase-induced pulmonary emphysema in mice: effects of ambient existing particulate matters. Int Immunopharmacol. 2010;10(11):1380-9.

31. Cohen J, Van Marter LJ, Sun Y, Allred E, Leviton A, Kohane IS. Perturbation of gene expression of the chromatin remodeling pathway in premature newborns at risk for bronchopulmonary dysplasia. Genome Biol. 2007;8(10): R210.

32. Collins JJP, Lithopoulos MA, Dos Santos CC, Issa N, Mobius MA, Ito C, et al. Impaired Angiogenic supportive capacity and altered gene expression profile of resident CD146(+) Mesenchymal stromal cells isolated from Hyperoxia-injured neonatal rat lungs. Stem Cells Dev. 2018;27(16):1109-24.

33. Hamelmann E, Schwarze J, Takeda K, Oshiba A, Larsen GL, Irvin CG, et al. Noninvasive measurement of airway responsiveness in allergic mice using barometric plethysmography. Am J Respir Crit Care Med. 1997;156(3 Pt 1): 766-75.

34. Dohi M, Tsukamoto S, Nagahori T, Shinagawa K, Saitoh K, Tanaka Y, et al. Noninvasive system for evaluating the allergen-specific airway response in a murine model of asthma. Lab Investig. 1999;79(12):1559-71.

35. Albacker LA, Chaudhary V, Chang YJ, Kim HY, Chuang YT, Pichavant M, et al. Invariant natural killer $T$ cells recognize a fungal glycosphingolipid that can induce airway hyperreactivity. Nat Med. 2013;19(10):1297-304.

36. Scholzen T, Gerdes J. The Ki-67 protein: from the known and the unknown. J Cell Physiol. 2000;182(3):311-22.

37. Li J, Li Y, He H, Liu C, Li W, Xie L, et al. Csk/Src/EGFR signaling regulates migration of myofibroblasts and alveolarization. Am J Phys Lung Cell Mol Phys. 2016;310(6):L562-71.

38. Tang K, Rossiter HB, Wagner PD, Breen EC. Lung-targeted VEGF inactivation leads to an emphysema phenotype in mice. J Appl Physiol. 2004;97(4): 1559-66 discussion 49

39. Goncharova EA, Goncharov DA, James ML, Atochina-Vasserman EN, Stepanova V, Hong SB, et al. Folliculin controls lung alveolar enlargement and epithelial cell survival through E-cadherin, LKB1, and AMPK. Cell Rep. 2014;7(2):412-23.

40. Metzger DE, Stahlman MT, Shannon JM. Misexpression of ELF5 disrupts lung branching and inhibits epithelial differentiation. Dev Biol. 2008;320(1):14960.

41. Fineschi S, De Cunto G, Facchinetti F, Civelli M, Imbimbo BP, Carnini C, et al. Receptor for advanced glycation end products contributes to postnatal pulmonary development and adult lung maintenance program in mice. Am J Respir Cell Mol Biol. 2013;48(2):164-71.

42. Petrache I, Natarajan V, Zhen L, Medler TR, Richter AT, Cho C, et al. Ceramide upregulation causes pulmonary cell apoptosis and emphysemalike disease in mice. Nat Med. 2005;11(5):491-8.

43. Becker PM, Tran TS, Delannoy MJ, He C, Shannon JM, McGrath-Morrow S Semaphorin 3A contributes to distal pulmonary epithelial cell differentiation and lung morphogenesis. PLoS One. 2011;6(11):e27449.

44. Mandeville I, Aubin J, LeBlanc M, Lalancette-Hebert M, Janelle MF, Tremblay $\mathrm{GM}$, et al. Impact of the loss of Hoxa5 function on lung alveogenesis. Am J Pathol. 2006;169(4):1312-27.

45. Chen H, Sun J, Buckley S, Chen C, Warburton D, Wang XF, et al. Abnormal mouse lung alveolarization caused by Smad3 deficiency is a developmental antecedent of centrilobular emphysema. Am J Phys Lung Cell Mol Phys. 2005:288(4):L683-91.

46. Rackley CR, Stripp BR. Building and maintaining the epithelium of the lung. J Clin Invest. 2012;122(8):2724-30

47. Du Y, Guo M, Whitsett JA, Xu Y. 'LungGENS': a web-based tool for mapping single-cell gene expression in the developing lung. Thorax. 2015;70(11):1092-4

48. Colarossi C, Chen Y, Obata H, Jurukovski V, Fontana L, Dabovic B, et al. Lung alveolar septation defects in Ltbp-3-null mice. Am J Pathol. 2005;167(2):419-28.

49. Wang $Y$, Tang $Z$, Huang $H$, Li J, Wang $Z$, Yu $Y$, et al. Pulmonary alveolar type I cell population consists of two distinct subtypes that differ in cell fate. Proc Natl Acad Sci U S A. 2018;115(10):2407-12.

50. Yadav S, Puri S, Linstedt AD. A primary role for Golgi positioning in directed secretion, cell polarity, and wound healing. Mol Biol Cell. 2009; 20(6):1728-36.
51. Vyas-Read S, Wang W, Kato S, Colvocoresses-Dodds J, Fifadara NH, Gauthier TW, et al. Hyperoxia induces alveolar epithelial-to-mesenchymal cell transition. Am J Phys Lung Cell Mol Phys. 2014;306(4):L326-40.

52. Turrens JF, Freeman BA, Crapo JD. Hyperoxia increases $\mathrm{H} 2 \mathrm{O} 2$ release by lung mitochondria and microsomes. Arch Biochem Biophys. 1982;217(2): 411-21.

53. Gouveia L, Betsholtz C, Andrae J. PDGF-A signaling is required for secondary alveolar septation and controls epithelial proliferation in the developing lung. Development. 2018;145:7.

54. Bonello MR, Bobryshev YV, Khachigian LM. Peroxide-inducible Ets-1 mediates platelet-derived growth factor receptor-alpha gene transcription in vascular smooth muscle cells. Am J Pathol. 2005;167(4):1149-59.

55. Lin C, Chen MH, Yao E, Song H, Gacayan R, Hui CC, et al. Differential regulation of Gli proteins by Sufu in the lung affects PDGF signaling and myofibroblast development. Dev Biol. 2014;392(2):324-33.

56. Zhang N, Chan CW, Sanchez-Guerrero E, Khachigian LM. Repression of PDGF-R-alpha after cellular injury involves TNF-alpha, formation of a c-FosYY1 complex, and negative regulation by HDAC. Am J Phys Cell Physiol. 2012;302(11):C1590-8

57. Wang $P, X u$ J, Hou Z, Wang F, Song $Y$, Wang J, et al. miRNA-34a promotes proliferation of human pulmonary artery smooth muscle cells by targeting PDGFRA. Cell Prolif. 2016:49(4):484-93.

58. Ruiz-Camp J, Quantius J, Lignelli E, Arndt PF, Palumbo F, Nardiello C, et al. Targeting miR-34a/Pdgfra interactions partially corrects alveologenesis in experimental bronchopulmonary dysplasia. EMBO molecular medicine. 2019;11:3.

59. Wang $Y Z$, Zhang P, Rice AB, Bonner JC. Regulation of interleukin-1beta -induced platelet-derived growth factor receptor-alpha expression in rat pulmonary myofibroblasts by p38 mitogen-activated protein kinase. J Biol Chem. 2000;275(29):22550-7.

60. Deng X, Jin K, Li Y, Gu W, Liu M, Zhou L. Platelet-derived growth factor and transforming growth factor beta1 regulate ARDS-associated lung fibrosis through distinct signaling pathways. Cell Physiol Biochem. 2015;36(3):93746.

61. Ingram JL, Rice AB, Geisenhoffer K, Madtes DK, Bonner JC. IL-13 and IL-1beta promote lung fibroblast growth through coordinated up-regulation of PDGF-AA and PDGF-Ralpha. FASEB J. 2004;18(10):1132-4.

62. Tejada ML, Yu L, Dong J, Jung K, Meng G, Peale FV, et al. Tumor-driven paracrine platelet-derived growth factor receptor alpha signaling is a key determinant of stromal cell recruitment in a model of human lung carcinoma. Clin Cancer Res. 2006;12(9):2676-88.

\section{Publisher's Note}

Springer Nature remains neutral with regard to jurisdictional claims in published maps and institutional affiliations.

Ready to submit your research? Choose BMC and benefit from:

- fast, convenient online submission

- thorough peer review by experienced researchers in your field

- rapid publication on acceptance

- support for research data, including large and complex data types

- gold Open Access which fosters wider collaboration and increased citations

- maximum visibility for your research: over $100 \mathrm{M}$ website views per year

At $\mathrm{BMC}$, research is always in progress.

Learn more biomedcentral.com/submission 